\title{
Fukinolic acid and cimicifugic acids: a review
}

\author{
Anne Jahn - Maike Petersen $(\mathbb{D}$
}

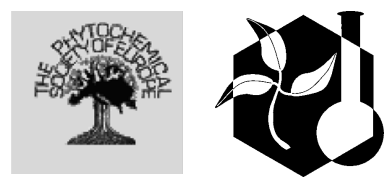

Received: 7 April 2021/Accepted: 19 September 2021 / Published online: 23 October 2021

(C) The Author(s) 2021

\begin{abstract}
During the last decades, the research on the biological activities of extracts from Cimicifugal Actaea species and Petasites japonicus as well as their active ingredients has been intensified. Besides terpenoids as dominant natural product group, hydroxycinnamic acid esters such as fukinolic acid and several cimicifugic acids have been isolated from Actaea and Petasites species and their chemical structures have been elucidated. Investigations on the biological properties of these hydroxycinnamic acid esters are currently undertaken and some compounds might be promising therapeutic tools. In this review, we have gathered information on the genera Actaea and Petasites, the occurrence of cimicifugic and fukinolic acids and some aspects of their biosynthesis. Furthermore, we have summarized the medicinal aspects of fukinolic acid and cimicifugic acids. In connection with the biological activities of these compounds, structural features of the hydroxycinnamic acid derivatives move into the focus. The position of the hydroxyl group at the aromatic rings and the introduction of an electron-donating moiety may be important for anti-inflammatory, antiviral, cytotoxic and vasoactive effects of these compounds.
\end{abstract}

\footnotetext{
A. Jahn $\cdot$ M. Petersen ( $\square)$

Institut für Pharmazeutische Biologie und Biotechnologie,

Philipps-Universität Marburg, Robert-Koch-Str. 4,

35037 Marburg, Germany

e-mail: petersen@staff.uni-marburg.de
}

Keywords Actaea racemosa (syn. Cimicifuga racemosa $\cdot$ Ranunculaceae) - Cimicifugic/fukinolic acids · Fukiic acid · Hydroxycinnamic acid esters · Petasites japonicus (Asteraceae) · Piscidic acid

\section{Introduction}

The use of herbs and herbal extracts for therapeutic aspects goes back a long time from a historical perspective. A multitude of plants have been used in traditional medicine, among them Actaea (syn. Cimicifuga) and Petasites species. Both species grow in the northern parts of our planet, namely Eastern Asia, North America and Europe. Different plant organs have been traditionally used for the treatment of common diseases such as gastroenteritis, bronchitis, postmenopausal symptoms, sore throat and headaches (Aydin et al. 2013; Chen et al. 2014; Henneicke-vonZepelin 2017; Guo et al. 2017).

Various active compounds besides the hydroxycinnamic acid esters (fukinolic and cimicifugic acids) have been described from Actaea and Petasites species and their biological effects have been investigated. A major active group in Petasites are sesquiterpenes, especially petasin and its isomers that possess neuroprotective effects (Wang et al. 2013) as well as spasmolytic (Aydin et al. 2013) and antiinflammatory activities (Thomet et al. 2001). Further 
metabolites are pyrrolizidine alkaloids (Kitajima et al. 2019 and literature cited therein), some of which have carcinogenic and hepatotoxic properties. Flavonoids (Kim et al. 2017), lignans (Min et al. 2005) and essential oil (Miyazawa et al. 2003) have been found in Petasites japonicus as well.

Actaea species are widely used in traditional Chinese medicine and have been traditionally used by Native Americans. This has been comprehensively reviewed by Guo et al. (2017). In the European Pharmacopoeia, an extract from rhizomes of A. racemosa is recommended as "Herbal medicinal product for the relief of menopausal complaints such as hot flushes and profuse sweating" (EMA/HMPC/48745/ 2017). The pharmacological properties of Actaea racemosa have very recently been compiled by Salari et al. (2021). The pharmaceutically most recognized compounds of Actaea species are triterpene glycosides with a cycloartane skeleton such as actein (acetylacteol-3- $O$-D-xyloside). Various structurally different triterpene aglyca have been identified: cimigenol, 25-dehydrocimigenol, acteol, 23-epi-acteol, 23-Oacetylshengmanol, hydroshengmanol, cimiracemoside, neocimigenol, isodahurinol, cimicidanol and cimicidol (Qiu et al. 2014). These compounds were reported to have cytotoxic, antiviral, anti-proliferative and anti-tumor activities (Watanabe et al. 2002; Sakurai et al. 2003, 2004). The triterpene glycosides are supposed to be the active compounds for the treatment of postmenopausal symptoms (Leach and Moore 2012). Some nitrogen-containing compounds have been identified as well, e.g. cimipronidine (a guanidine alkaloid), cyclocimipronidine or cimipronidine methyl ester, $N_{\omega}$-methylserotonin, salsolinol or dopargine (Qiu et al. 2014). Nikolić et al. (2012) identified at least 73 nitrogen-containing primary and secondary compounds in A. racemosa, among them aporphine alkaloids, isoquinoline alkaloids, protoberberine alkaloids, protopine alkaloids, betains, guanidines, choline derivatives, $\beta$-carboline alkaloids, amides of hydroxycinnamic acids and pyridoxine derivatives. A comprehensive compilation of natural products from Cimicifuga species can be found in the review by Guo et al. (2017).

Apart from the already mentioned active specialized compounds of the genera Actaea and Petasites, hydroxycinnamic acid esters are becoming increasingly important. Since the first isolation of fukinolic acid from P. japonicus (Sakamura et al. 1969) its medicinal properties have been investigated (Sakamura et al. 1973; Löser et al. 2000; Watanabe et al. 2007). Later, further hydroxycinnamic acid esters, congeners of fukinolic acid, have been isolated, mostly from Actaea species, and were named cimicifugic acids $\mathrm{A}-\mathrm{N}$ in the order of their discovery (Gödecke et al. 2009).

According to current knowledge cimicifugic acids show a variety of pharmacological effects. The biological effects of cimicifugic acids and fukinolic acid comprise estrogenic, anti-tumor and collagenolytic activities (Kruse et al. 1999; Kusano et al. 2001; Jiang et al. 2008b), inhibition of hyaluronidase and cytochrome P450 enzymes (Iwanga et al. 2010a, b; Huang et al. 2010) and the influence on seed germination and seedling growth (Kusano et al. 1998). Furthermore, cimicifugic acids and fukinolic acid were found to possess anti-inflammatory (Löser et al. 2000; Wang et al. 2017b; Lee et al. 2019), antiviral (Powers and Setzer 2016; Ma et al. 2019), antioxidant properties (Burdette et al. 2002; Nuntanakorn et al. 2006, 2007; Watanabe et al. 2007) and additionally vasoactive (Noguchi et al. 1998) and miscellaneous other effects (Shimoda et al. 2006; Farnsworth et al. 2008). These will be further discussed in this review.

Although, a multitude of biological activities of fukinolic and cimicifugic acids have been published, there is currently no review that focusses on the importance of fukinolic acid and cimicifugic acids. The aim of this review is to shortly present the botanical aspects of plant species containing fukinolic acid and cimicifugic acids. Furthermore, the occurrence of hydroxycinnamic acid esters and their benzyltartaric acid moieties are summarized as well as the current knowledge of their biosynthesis. The main part will be information on the structural compositions of the acids that influence the pharmacological effects and the evaluation of the effectiveness of cimicifugic acids and fukinolic acid as potential drugs. To establish this review, we have searched the literature published in English or having at least an English abstract using SciFinder and Google Scholar and the following keywords: Actaea, Cimicifuga, Petasites japonicus, fukinolic acid, cimicifugic acid, fukiic acid, piscidic acid. To our knowledge, no relevant publication has been excluded. 


\section{Botanical aspects of Actaea species and Petasites japonicus}

Petasites (Asteraceae) and Actaea (Ranunculaceae) species are distributed in the northern hemisphere, occurring in Eastern Asia, North America and Europe. Only those Actaea species that are officially of therapeutic use in China and Europe will be described here, even if there are further species containing cimicifugic acids and fukinolic acid. Furthermore, Petasites japonicus is presented here which has been introduced to Europe as an ornamental plant (Ożarowski et al. 2013) and, unlike other Petasites species (to our current knowledge), contains fukinolic acid.

\section{Actaea species}

Actaea species are native to subarctic, temperate and subtropical habitats of the northern hemisphere. The former genus Cimicifuga was included in the genus Actaea in 1998 due to molecular phylogenetic data showing a monophyletic clade of the former genera Actaea, Cimicifuga and Souliea (Compton et al. 1998). The genus Actaea now comprises about 30 species (World Flora Online http://www.worldfloraonline. org, accessed August 12, 2021). Different species of the genus Actaea (Ranunculaceae) are commonly used in the traditional Chinese herbal medicine, here still registered as the genus Cimicifuga. According to the Pharmacopoeia of China the official Cimicifugae rhizoma can include rhizomes of Actaea foetida, A. heracleifolia and A. dahurica (Guo et al. 2017). The quality of Cimicifugae rhizoma is controlled by the content of isoferulic acid (Shen et al. 2013). In Europe, only A. racemosa is of therapeutic relevance (European Union herbal monograph on Cimicifuga racemosa (L.) Nutt. rhizoma EMA/HMPC/48745/ 2017). Cimicifuga has got its name because of the unpleasant smell of the flowers that repels insects like leaf bugs: lat. cimex = bug and fuga = escape (Cimicifuga $=$ bugweed) (Blaschek 2016). Most species are perennial and herbaceous plants that grow up to two meters and flower in late summer until early autumn.

The small, dense, white or creamy white flowers are arranged in a long, narrow, complex inflorescence. This inflorescence is characterized by numerous terminate clustered racemes that can vary from simple to spicate or branched. The cup consists of 4 or 5 petaloid white sepals that are orbovate-orbicular and caduceus. The flowers are dominated by the numerous stamens. Actaea species possess stems with various apical branches and carry large, long-stemmed pinnate compound leaves. The few yellow-brown seeds develop in autumn and are ellipsoid, narrow and flat. The dried rootstock of Actaea is used for extraction and pharmaceutical applications. The fibrous, cylindrical roots and creeping, crawling rhizomes are characterized by a dark brown color and robust consistence (Blaschek 2016; Guo et al. 2017).

\section{Petasites japonicus}

Petasites japonicus (Asteraceae) is native to Eastern Asia. The rhizomes, roots and leaves of $P$. japonicus are commonly used in the USA as dietary supplement. In Japan, the young petioles are used as legumes and in traditional medicine. The common name of the genus Petasites is butterbur, probably because the large leaves were used to wrap butter in them for storage (Lee et al. 2019). P. japonicus is a perennial dioecious herbaceous plant flowering during April and May. The plant is characterized by its basal relatively large rhubarb-like green leaves which develop after flowering. The leaves are smooth, the upper side of the leaf is glabrous, whereas the lower side is thickly covered by trichomes. The flowers are greenish-white and usually either male or female. The primary inflorescence is a flower head, while the secondary inflorescence is a raceme. The petioles are light grey, fuzzy and hollow and the plant possesses thick rhizomes (Sakai et al. 2008; Tys et al. 2015).

\section{Biogenetic origin of hydroxycinnamic acid esters}

The phenolic compounds considered in this review are specialized metabolites derived from the shikimate pathway, which gives rise to the aromatic amino acids L-phenylalanine and L-tyrosine (besides L-tryptophan). Both moieties of cimicifugic and fukinolic acids are derived from these two amino acids (probably with exception of cimicifugic acid $\mathrm{H}$ with 3,4-dihydroxybenzoic acid as acid moiety; Iwanaga et al. 2010a). The phenylpropanoid pathway starting with L-phenylalanine gives rise to the hydroxycinnamic acid part and L-tyrosine probably is the precursor for the 
alcoholic acceptor moiety, namely piscidic and fukiic acid (see below).

\section{Nomenclature of fukinolic acid and cimicifugic acids and related compounds}

From a chemical point of view, cimicifugic acids and fukinolic acid are classified as hydroxycinnamic acid esters (although cimicifugic acid $\mathrm{H}$ as a benzoic acid ester is an exception). They are composed of a glycolated hydroxyphenyllactic acid moiety, namely fukiic acid ((3,4-dihydroxybenzyl)tartaric acid) or piscidic acid ((4-hydroxybenzyl)tartaric acid), or benzyltartaric acid (for cimicifugic acid $\mathrm{M}$ ), and a hydroxycinnamic or benzoic acid (cimicifugic acid $\mathrm{H}$ ) moiety (Fig. 1). Piscidic and fukiic acid have the same stereochemistry, possess the same side chain and only differ by number of hydroxyl groups at the aromatic ring (Yoshihara et al. 1974).

Fukinolic acid has been first isolated from Petasites japonicus and its structure has been elucidated as an ester of caffeic acid and fukiic acid (Sakamura et al. 1973). Similar esters isolated from Actaea species have been named cimicifugic acids. Their "old" names cimicifugic acids $\mathrm{A}$ to $\mathrm{N}$ were given in the order of their detection (Gödecke et al. 2009).

A structure-based nomenclature has been established by Gödecke et al. (2009) taking the structural properties of cimicifugic acids into account (Fig. 1). Consequently, the cimicifugic acids (CA) were named with two letters to clarify the condensation products as follows: piscidic acid (P) or fukiic acid $(\mathrm{K})$ connected with cinnamic acid (C), 4-coumaric acid (P), 4-methoxycinnamic acid (M), caffeic acid (K), ferulic acid (F), isoferulic acid (I), 3,4-dimethoxycinnamic acid (D) and sinapic acid (S). The abbreviation " $\mathrm{C}$ ", however, was used for caffeic acid (instead of cinnamic acid) by Qiu et al. (2014) leading to the name CA KC for fukinolic acid instead of CA KK as proposed by Gödecke et al. (2009). Besides the structures and the nomenclature, Fig. 1 also includes some chemical and physical properties of these hydroxycinnamic acid esters.<smiles>C[C@](O)([C@@H](O)[C@](C)(O)Cc1ccc(O)c(O)c1)[C@](C)(O)Cc1ccc(O)cc1</smiles><smiles>[R]c1ccc(C[C@](O)(C(=O)O)[C@@H](OC(=O)/C=C/c2cc([R6])c([R4])c([R6])c2)C(=O)O)cc1[R]</smiles>

\begin{tabular}{|c|c|c|c|c|c|c|c|c|c|c|c|c|}
\hline R1 & R2 & ...acid & R3 & R4 & R5 & ...acid & $\begin{array}{c}\text { first compound } \\
\text { name }\end{array}$ & $\begin{array}{c}\begin{array}{c}\text { systematic } \\
\text { name }\end{array} \\
\end{array}$ & & $\begin{array}{c}\text { molecular } \\
\text { mass }\end{array}$ & $\lambda_{\max }[\mathrm{nm}]$ & $\log \varepsilon$ \\
\hline $\mathrm{OH}$ & $\mathrm{OH}$ & fukiic $(K)$ & $\mathrm{OH}$ & $\mathrm{OH}$ & $\mathrm{H}$ & caffeic & fukinolic acid & CA KK & $\mathrm{C}_{20} \mathrm{H}_{18} \mathrm{O}_{11}$ & 434.35 & 332 & 4.26 \\
\hline $\mathrm{OH}$ & $\mathrm{OH}$ & fukiic $(K)$ & $\mathrm{OCH}_{3}$ & $\mathrm{OH}$ & $\mathrm{H}$ & ferulic & cimicifugic acid $\mathrm{A}$ & CA KF & $\mathrm{C}_{21} \mathrm{H}_{20} \mathrm{O}_{11}$ & 448.376 & 328 & 4.28 \\
\hline $\mathrm{OH}$ & $\mathrm{OH}$ & fukiic (K) & $\mathrm{OH}$ & $\mathrm{OCH}_{3}$ & $\mathrm{H}$ & isoferulic & cimicifugic acid $B$ & CA KI & $\mathrm{C}_{21} \mathrm{H}_{20} \mathrm{O}_{11}$ & 448.376 & 313 & 4.27 \\
\hline $\mathrm{OH}$ & $\mathrm{OH}$ & fukiic $(K)$ & $\mathrm{H}$ & $\mathrm{OH}$ & $\mathrm{H}$ & 4-coumaric & cimicifugic acid $\mathrm{C}$ & CA KP & $\mathrm{C}_{20} \mathrm{H}_{18} \mathrm{O}_{10}$ & 418.35 & 313 & 4.27 \\
\hline $\mathrm{H}$ & $\mathrm{OH}$ & piscidic $(\mathrm{P})$ & $\mathrm{OH}$ & $\mathrm{OH}$ & $\mathrm{H}$ & caffeic & cimicifugic acid $\mathrm{D}$ & CA PK & $\mathrm{C}_{20} \mathrm{H}_{18} \mathrm{O}_{10}$ & 418.35 & 332 & 4.25 \\
\hline $\mathrm{H}$ & $\mathrm{OH}$ & piscidic $(\mathrm{P})$ & $\mathrm{OCH}_{3}$ & $\mathrm{OH}$ & $\mathrm{H}$ & ferulic & cimicifugic acid $\mathrm{E}$ & CA PF & $\mathrm{C}_{21} \mathrm{H}_{20} \mathrm{O}_{10}$ & 432.377 & 325 & 4.16 \\
\hline $\mathrm{H}$ & $\mathrm{OH}$ & piscidic $(P)$ & $\mathrm{OH}$ & $\mathrm{OCH}_{3}$ & $\mathrm{H}$ & isoferulic & cimicifugic acid $\mathrm{F}$ & CA PI & $\mathrm{C}_{21} \mathrm{H}_{20} \mathrm{O}_{10}$ & 432.377 & 326 & 4.25 \\
\hline $\mathrm{OH}$ & $\mathrm{OH}$ & fukiic $(\mathrm{K})$ & $\mathrm{OCH}_{3}$ & $\mathrm{OCH}_{3}$ & $\mathrm{H}$ & $\begin{array}{c}\text { trans-3,4- } \\
\text { dimethoxycinnamic }\end{array}$ & cimicifugic acid $\mathrm{G}$ & CA KD & $\mathrm{C}_{22} \mathrm{H}_{22} \mathrm{O}_{11}$ & 462.403 & 328 & 3.17 \\
\hline $\mathrm{OH}$ & $\mathrm{OH}$ & fukiic $(K)$ & \multicolumn{3}{|c|}{$\begin{array}{l}\text { 3,4-dihydroxybenzoic } \\
\text { acid }\end{array}$} & $\begin{array}{l}\text { 3,4-dihydroxy- } \\
\text { benzoic }\end{array}$ & cimicifugic acid $\mathrm{H}$ & - & $\mathrm{C}_{18} \mathrm{H}_{16} \mathrm{O}_{10}$ & 392.313 & 324 & 4.2 \\
\hline $\mathrm{OH}$ & $\mathrm{OH}$ & fukiic (K) & $\mathrm{OCH}_{3}$ & $\mathrm{OH}$ & $\mathrm{OCH}_{3}$ & sinapic & cimicifugic acid I & CA KS & $\mathrm{C}_{22} \mathrm{H}_{22} \mathrm{O}_{12}$ & 478.402 & 331 & 4.1 \\
\hline $\mathrm{H}$ & $\mathrm{OH}$ & piscidic $(\mathrm{P})$ & $\mathrm{OCH}_{3}$ & $\mathrm{OH}$ & $\mathrm{OCH}_{3}$ & sinapic & cimicifugic acid $\mathrm{J}$ & CA PS & $\mathrm{C}_{22} \mathrm{H}_{22} \mathrm{O}_{11}$ & 462.403 & 329 & 4.04 \\
\hline $\mathrm{H}$ & $\mathrm{OH}$ & piscidic $(\mathrm{P})$ & $\mathrm{H}$ & $\mathrm{OH}$ & $\mathrm{H}$ & 4-coumaric & cimicifugic acid $\mathrm{K}$ & CA PP & $\mathrm{C}_{20} \mathrm{H}_{18} \mathrm{O}_{9}$ & 402.351 & 316 & 4.4 \\
\hline $\mathrm{H}$ & $\mathrm{OH}$ & piscidic $(\mathrm{P})$ & $\mathrm{OCH}_{3}$ & $\mathrm{OCH}_{3}$ & H & $\begin{array}{c}\text { trans-3,4- } \\
\text { dimethoxycinnamic }\end{array}$ & cimicifugic acid $\mathrm{L}$ & CA PD & $\mathrm{C}_{22} \mathrm{H}_{22} \mathrm{O}_{10}$ & 446.404 & & \\
\hline $\mathrm{H}$ & $\mathrm{H}$ & $\begin{array}{l}\text { benzyl- } \\
\text { tartaric }\end{array}$ & $\mathrm{OH}$ & $\mathrm{OH}$ & $\mathrm{H}$ & caffeic & cimicifugic acid $\mathrm{M}$ & - & $\mathrm{C}_{20} \mathrm{H}_{18} \mathrm{O}_{9}$ & 402.351 & & \\
\hline $\mathrm{OH}$ & $\mathrm{OH}$ & fukiic $(K)$ & $\mathrm{OCH}_{3}$ & $\mathrm{OCH}_{3}$ & $\mathrm{H}$ & $\begin{array}{c}\text { cis-3,4- } \\
\text { dimethoxycinnamic }\end{array}$ & cimicifugic acid $\mathrm{N}$ & [CA KDcis] & $\mathrm{C}_{22} \mathrm{H}_{22} \mathrm{O}_{11}$ & 462.403 & 325 & 4.24 \\
\hline
\end{tabular}

Fig. 1 Nomenclature of cimicifugic acids and fukinolic acid according to Gödecke et al. (2009) modified after Werner and Petersen (2019). $\lambda_{\max }$ and $\log \varepsilon$ values (methanol) are taken from Yannai (2012) 
In addition, shomasides $\mathrm{A}$ and $\mathrm{B}$ have been isolated from A. dahurica/A. heracleifolia. They are galactosides of cimicifugic acids $\mathrm{A}$ and $\mathrm{E}$, respectively. Shomaside C from the same plant species is a glucoside of cimicifugic acid $\mathrm{E}$. In all cases, the sugar moieties are attached to the 4-OH-group of the ferulic acid part (Iwanaga et al. 2010a; Yim et al. 2012a).

\section{Biosynthesis of fukinolic and cimicifugic acids}

Fukinolic acid and most cimicifugic acids are esters composed of a benzyltartaric acid moiety and a hydroxycinnamic acid moiety (Fig. 1). The formation of fukinolic acid has been investigated by Hasa and Tazaki (2004). Five isotope-labeled compounds have been fed to axenically cultivated plants of Petasites japonicus: $\left[1,2-{ }^{13} \mathrm{C}_{2}\right]$ and $\left[2-{ }^{13} \mathrm{C}\right]$ sodium acetate, $\left[2-{ }^{13} \mathrm{C}\right]$ malonic acid, $\left[3-{ }^{13} \mathrm{C}\right] \mathrm{L}-$ phenylalanine and $\left[1-{ }^{13} \mathrm{C}\right] \mathrm{L}$-tyrosine. Based on these ${ }^{13} \mathrm{C}$-labeling experiments, $\mathrm{L}$-tyrosine and acetate were incorporated into the benzyltartaric acid moiety and L-phenylalanine into the caffeic acid moiety of fukinolic acid (Fig. 2). According to these ${ }^{13} \mathrm{C}$-labeling experiments the synthesis of fukiic acid is based on 4-hydroxyphenylpyruvic acid or-as we suggest-4-hydroxyphenyllactic acid derived from L-tyrosine while the glycol side-chain is derived from acetate. Thus, Hasa and Tazaki (2004) proposed the introduction of an acetyl unit either from acetic acid or from acetyl-CoA. This, however, leaves the source of the OH-group needed for esterification open. Whether the biosynthesis takes place in the whole plant or in specific plant organs has not been reported.

The caffeic acid moiety of fukinolic acid is proposed to be synthesized by the conversion of $\left[3-{ }^{13} \mathrm{C}\right]$ L-phenylalanine into caffeoyl-CoA by the well-known phenylpropanoid pathway. The esterification of the caffeic acid moiety from caffeoyl-CoA and fukiic acid finally leads to fukinolic acid. Alternatively, fukiic acid could be coupled to 4-coumaric acid with 3-hydroxylation following the esterification.

Whereas the cinnamic acid moiety of cimicifugic acids is quite variable, the benzyltartaric acid moiety is - to our present knowledge-restricted to piscidic and fukiic acid (Fig. 1) with exception of cimicifugic acid $\mathrm{M}$ where the benzyltartaric acid part carries no hydroxylation at the aromatic ring (Iwanaga et al. 2010b). To our best knowledge, there is currently no published information on neither the site of synthesis, nor the transport of these compounds, nor their subcellular localization. However, undifferentiated callus and suspension cultures of Petasites japonicus as well as Actaea racemosa accumulate fukinolic and cimicifugic acids to some extent (own unpublished results), thus specialized organs may not be essential.

The biosynthesis of cimicifugic acids has not been investigated on enzyme and gene levels until recently and still requires further investigation. Our group identified a hydroxycinnamoyltransferase from $A c$ taea racemosa (Werner and Petersen 2019). This enzyme, namely hydroxycinnamoyl-CoA:piscidic acid hydroxycinnamoyltransferase (ArHPT1) or cimicifugic acid synthase (CAS), transfers a hydroxycinnamic acid moiety from hydroxycinnamoyl-CoA to piscidic acid (Fig. 3). Four hydroxycinnamoyl-CoA thioesters have been accepted by CAS. The highest affinity has been measured for $p$-coumaroyl-CoA with a $\mathrm{K}_{\mathrm{m}}$ of $6.8 \mu \mathrm{M} \pm 2.3 \mu \mathrm{M}$. In contrast, the lowest substrate affinity has been detected for feruloyl-CoA $\left(\mathrm{K}_{\mathrm{m}} 51.4 \mu \mathrm{M} \pm 11.8 \mu \mathrm{M}\right)$. Caffeoyl$\mathrm{CoA}\left(\mathrm{K}_{\mathrm{m}} \quad 16.3 \mu \mathrm{M} \pm 4.6 \mu \mathrm{M}\right)$ and sinapoyl-CoA $\left(\mathrm{K}_{\mathrm{m}} 10.5 \mu \mathrm{M} \pm 2.7 \mu \mathrm{M}\right)$ are ranged in between. The products resulting from the catalytic activity of CAS are cimicifugic acids as follows: CA PK (with caffeoyl-CoA), CA PF (with feruloyl-CoA), CA PS (with sinapoyl-CoA) and CA PP (with $p$-coumaroyl$\mathrm{CoA}$ ). As CAS is a soluble enzyme localization of this part of the biosynthesis in the cytosol can be assumed.

\section{Occurrence and biological functions of fukiic and piscidic acids}

Whereas various hydroxycinnamic acid esters as e.g. chlorogenic acid or rosmarinic acid are wide-spread in the plant kingdom, hydroxycinnamic acid esters with benzyltartaric acids, namely fukiic and piscidic acid, are less widely distributed. Examples for the occurrence of piscidic and fukiic acid as free acids are given in Table 1. Surprisingly, fukiic and piscidic acids occur in a number of genera of various families, without fukinolic acid or cimicifugic acids being detected at the same time, since fukinolic acid and cimicifugic acids, however, have to date only been detected in a few genera (Table 2).

Piscidic acid has been found in species of the monocotyledonous plant families Amaryllidaceae, 

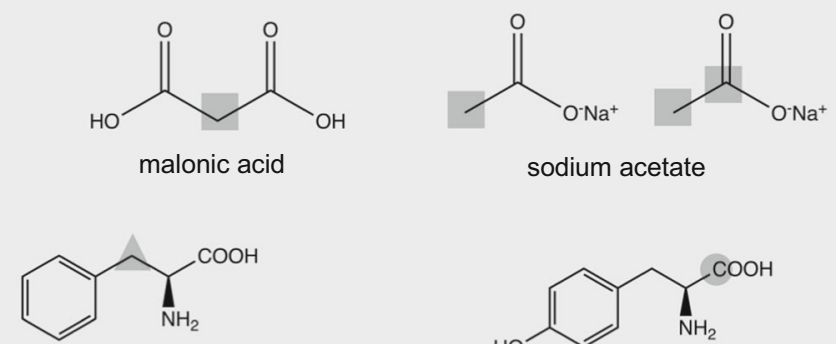

L-phenylalanine<smiles>N[C@@H](Cc1ccc(O)cc1)C(=O)O</smiles><smiles>O=C(O)/C=C/c1ccc(O)c(O)c1</smiles>

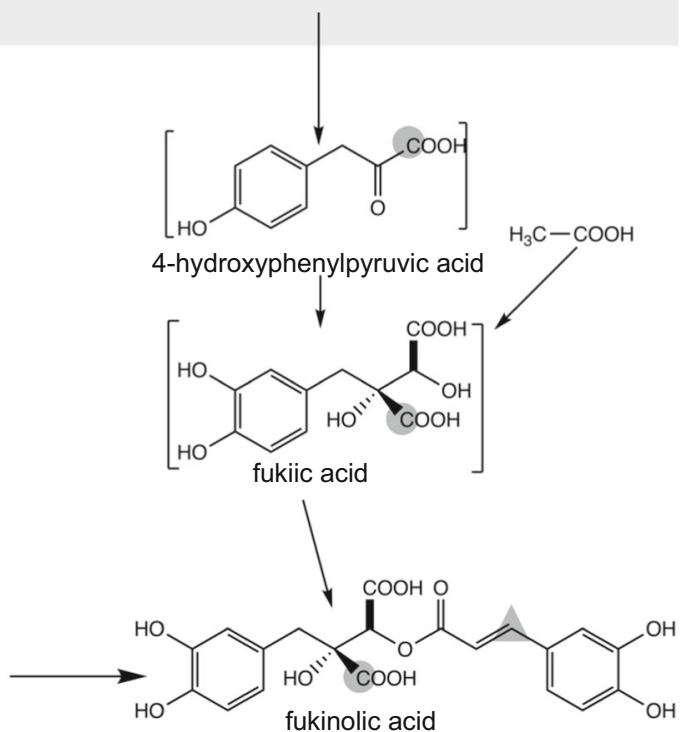

Fig. 2 Biosynthetic pathway of fukinolic acid as proposed by Hasa and Tazaki (2004). The grey symbols represent the ${ }^{13} \mathrm{C}$ labeled positions of the fed substrates (light grey box) and their precursor metabolites

Asparagaceae, Dioscoreaceae and Xanthorrhoeaceae as well as in the eudicot plant families Cactaceae, Euphorbiaceae, Fabaceae and Quillajaceae. Piscidic acid was reported to be an active compound of Dioscorea nipponica used to treat chronic bronchitis (Toshima et al. 1999). Moreover, piscidic acid is involved in the uptake of phosphate by roots of Cajanus cajan (Ishikawa et al. 2002).

Fukiic acid, on the other hand, is less widely distributed and has been isolated from species of the Asteraceae, Fabaceae and Myrtaceae. It was reported to be a main compound in the darkening process of Petasites japonicus tissues after cutting (Sakamura et al. 1973). Furthermore, synthetic racemic fukiic acid showed in vitro activities against HIV-1 integrase $\left(\mathrm{IC}_{50}=0.25 \mu \mathrm{M}\right)$ but failed to be active in antiviral assays with MT-4 cells (Queffelec et al. 2008).

\section{Occurrence of fukinolic acid and cimicifugic acids}

To our current knowledge, the occurrence of fukinolic acid and cimicifugic acids is mainly restricted to Actaea (Cimicifuga) species (Ranunculaceae) and to Petasites japonicus (Asteraceae) (Table 2). Apart from these two genera, cimicifugic acid D has been described to occur in Platycodon grandiflorum (Campanulaceae; Wang et al. 2017a), cimicifugic acids B and $\mathrm{E}$ in a peach flower extract (Prunus persica, Rosaceae; Kwak et al. 2018) and an unspecified cimicifugic acid in Desmodium styracifolium (Fabaceae; Zhao et al. 2007).

Since the initial isolation of fukinolic acid from leaves of Petasites japonicus (Sakamura et al. 1969) this compound has also been described in almost all Actaea species (see Table 2 and literature cited therein). Interestingly, the closely related cimicifugic 

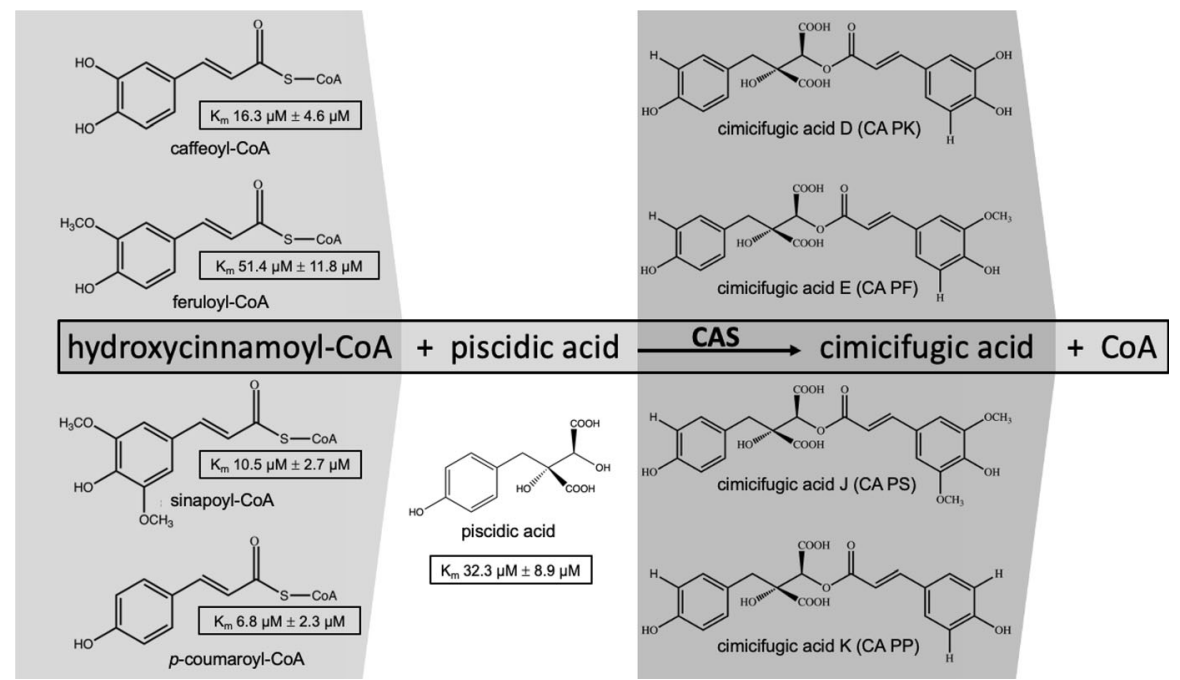

Fig. 3 Enzymatic formation of cimicifugic acids by cimicifugic acid synthase (CAS) from Actaea racemosa. CAS catalyzes the transfer of a hydroxycinnamic acid moiety from hydroxycinnamoyl-CoA thioesters (left grey box) to piscidic acid. The variety of the resulting cimicifugic acid products (grey box on the right-hand side) is determined by the four accepted

acids except cimicifugic acid D (Lee et al. 2019) have not been found in Petasites japonicus or other Petasites species. Furthermore, there are no reports about the occurrence of any fukinolic or cimicifugic acids from other Petasites species apart from $P$. japonicus. Cimicifuga rhizomes used in traditional Chinese medicine are composed of the species C. simplex, C. dahurica, C. heracleifolia and C. foetida (Kusano 2001; Yim et al. 2012b) whereas Cimicifugae rhizoma described in the European Pharmacopoeia only contains Cimicifuga (= Actaea) racemosa.

Besides free cimicifugic acids, Takahira et al. (1998a) isolated cimicifugic acids A, B, E and F as 1-methylester from A. simplex underground parts. Cimicifugic acid $\mathrm{E}$ and $\mathrm{F}$ 1-methylesters were also found in A. dahurica by Qin et al. (2017). Dehydrocimicifugic acids $\mathrm{A}$ and $\mathrm{B}$ were found by $\mathrm{Li}$ et al. (2003) in A. racemosa. Iwanaga et al. (2010a, b) furthermore detected glucosides and galactosides of cimicifugic acids in "Cimicifugae rhizoma" composed of A. heracleifolia and A. dahurica, namely shomaside $\mathrm{A}$ and $\mathrm{B}$ being cimicifugic acid $\mathrm{A}$ and $\mathrm{E}$ galactosides and shomaside $\mathrm{C}$ being cimicifugic acid E glucoside. substrates: caffeoyl-CoA $\left(\mathrm{K}_{\mathrm{m}} 16.3 \mu \mathrm{M} \pm 4.6 \mu \mathrm{M}\right)(\mathrm{CA} \mathrm{PK})$, feruloyl-CoA $\left(\mathrm{K}_{\mathrm{m}} 51.4 \mu \mathrm{M} \pm 11.8 \mu \mathrm{M}\right)$ (CA PF), sinapoyl$\mathrm{CoA}\left(\mathrm{K}_{\mathrm{m}} 10.5 \mu \mathrm{M} \pm 2.7 \mu \mathrm{M}\right)(\mathrm{CA} \mathrm{PS}), p$-coumaroyl-CoA $\left(\mathrm{K}_{\mathrm{m}}\right.$ $6.8 \mu \mathrm{M} \pm 2.3 \mu \mathrm{M}$ ) (CA PP) (data from Werner and Petersen 2019)

Unfortunately, quantitative data on the contents of fukinolic and cimicifugic acids in plant material are scarce. Investigations were made to optimize the extraction process of phenolic acids from A. racemosa (Mukhopadhyay et al. 2006). The influence of solvent, amount of extraction steps, temperature, pressure and particle size on the total yield of phenols of A. racemosa has been analyzed. A solvent mixture of methanol: $\mathrm{H}_{2} \mathrm{O}$ in a ratio of $60: 40(\mathrm{v} / \mathrm{v})$ was declared to be most suitable $\left(19.35 \mathrm{mg} / \mathrm{GAE} \mathrm{g}^{-1}\right)(\mathrm{GAE}=$ gallic acid equivalents). Furthermore, $92 \%$ of the phenols were isolated in the first two extraction steps. The yield of the first cycle was around $17.90 \mathrm{mg} / \mathrm{GAE} \mathrm{g}^{-1}$ ( $87 \%$ of the total phenols), followed by $1.81 \mathrm{mg} /$ $\mathrm{GAE} \mathrm{g}^{-1}(8.8 \%$ of the total phenols) in the second cycle and $4.2 \%$ in the third one $\left(0.86 \mathrm{mg} / \mathrm{GAE} \mathrm{g}^{-1}\right)$. The optimum extraction temperature was described with $90{ }^{\circ} \mathrm{C}\left(25.29 \mathrm{mg} / \mathrm{GAE} \mathrm{g}^{-1}\right)$ and the ideal range of particle size is given between 0.25 and $0.425 \mathrm{~mm}$. Unfortunately, this publication only gives insight into the total content of hydroxycinnamic acids and does not focus on the amount of their esterified derivatives.

Nuntanakorn et al. (2007) analyzed dried roots/ rhizomes of four different American Actaea species with respect to their hydroxycinnamic acids as well as fukinolic/cimicifugic acids. A. rubra displayed the 
Table 1 Examples for the occurrence of piscidic and fukiic acids in different plant species

\begin{tabular}{|c|c|c|c|}
\hline Compound & Plant family & Species & References \\
\hline \multirow[t]{21}{*}{ Piscidic acid } & \multirow[t]{3}{*}{ Amaryllidaceae } & Galanthus nivalis & Krogh (1969) \\
\hline & & Hippeastrum solandriflorum & Carvalho et al. (2015) \\
\hline & & Narcissus poeticus & Okumura et al. (1955) \\
\hline & Asparagaceae & Agave americana & Nordal and Ogner (1964), Krogh (1967) \\
\hline & \multirow[t]{2}{*}{ Cactaceae } & Opuntia ficus-indica & Nordal et al. (1966a), Teles et al. (1994), Missaoui et al. (2020) \\
\hline & & Coryphantha macromeris & Cabañas García et al. (2020) \\
\hline & Dioscoreaceae & Dioscorea nipponica & He et al. (1980), Ho et al. (1980) \\
\hline & Euphorbiaceae & Euphorbium resinifera & Krogh (1967) \\
\hline & \multirow[t]{11}{*}{ Fabaceae } & Piscidia erythrina & $\begin{array}{l}\text { Freer and Clover (1901), Bridge et al. (1948), Moore and Eng } \\
\text { (1956), Nordal et al. (1966b), Heller and Tamm (1975) }\end{array}$ \\
\hline & & Cajanus cajan & Ae et al. (1990), Otani et al. (1996), Ishikawa et al. (2002) \\
\hline & & Sophora tonkinensis & Ding and Chen (2008) \\
\hline & & Sophora alopecuroides & Wang and Ma (2009), Wang et al. (2020) \\
\hline & & Sophora flavescens & Zhang et al. (2013) \\
\hline & & Retama sphaerocarpa & Touati et al. (2017) \\
\hline & & Aspalathus pendula & Stander et al. (2017) \\
\hline & & Vicia faba & Valente et al. (2018) \\
\hline & & Albizia anthelmintica & Sobeh et al. (2020) \\
\hline & & Cyclopia spec. & Stander et al. (2019) \\
\hline & & Retama raetam & Saada et al. (2018) \\
\hline & Quillajaceae & Quillaja saponaria & Maier et al. (2015) \\
\hline & Xanthorrhoeaceae & Aloe zebrina & Krogh (1969) \\
\hline \multirow[t]{4}{*}{ Fukiic acid } & Asteraceae & Petasites japonicus & Sakamura et al. (1969), Sakamura et al. (1973) \\
\hline & \multirow[t]{2}{*}{ Fabaceae } & Piscidia erythrina & Heller and Tamm (1975) \\
\hline & & Vicia faba & Abu-Reidah et al. (2017) \\
\hline & Myrtaceae & Myrtus communis & Díaz de Cerio et al. (2018) \\
\hline
\end{tabular}

highest content of total phenolics with $2.92 \%$ of the dry weight, followed by A. podocarpa (1.71\%) whereas A. racemosa and A. pachypoda contained only $0.62 \%$ and $0.36 \%$, respectively. Fukinolic acid was the main ester in A. racemosa $(0.18 \%)$ and A. pachycarpa $(0.21 \%)$, followed by cimicifugic acid B in A. racemosa (0.16\%) and cimicifugic acid A $(0.12 \%)$ in A. pachycarpa. The main compound in A. podocarpa was cimicifugic acid A $(0.85 \%)$ closely followed by cimicifugic acid $\mathrm{E}$ $(0.81 \%)$. A. rubra contained $1.11 \%$ cimicifugic acid B, $0.77 \%$ fukinolic acid and $0.69 \%$ cimicifugic acid A. Yu et al. (2019) optimized the extraction protocol for A. dahurica in comparison to the protocol proposed by the European Pharmacopoeia and yielded appr. $0.01 \%$ cimicifugic acid $\mathrm{D}, 0.03 \%$ cimicifugic acid $\mathrm{B}, \quad 0.07 \%$ cimicifugic acid $\mathrm{E}$ and $0.10 \%$ cimicifugic acid $\mathrm{F}$ related to dry powdered plant material; the yields were increased by $31-57 \%$ compared to the standard extraction protocol. The drying process also has a strong impact on the contents of extractable phenolic acids. As determined by Qin et al. (2017) drying at higher temperatures $\left(90-110^{\circ} \mathrm{C}\right)$ resulted in higher yields. Amounts isolated from A. dahurica (dried at $110{ }^{\circ} \mathrm{C}$ ) ranged at $0.03 \%, 0.11 \%, 0.04 \%, 0.08 \%$ and $0.07 \%$ of the dry material for cimicifugic acids $\mathrm{A}, \mathrm{B}, \mathrm{D}, \mathrm{E}$ and $\mathrm{F}$, respectively. The extraction method as well as storage influenced the amounts of fukinolic acid and cimicifugic acids A and B. The primary extract contained $2.60 \%, 0.86 \%$ and $1.47 \%$ of these compounds which turned out to be stable for 9 weeks at room temperature (Jiang et al. 2008a). 
Table 2 Occurrence of fukinolic acid and cimicifugic acids in Actaea (Cimicifuga) species, Petasites japonicus, Platycodon grandiflorum and Prunus persica; FA fukinolic acid, $C A$ cimicifugic acid

\begin{tabular}{|c|c|c|c|c|c|c|c|c|c|c|c|c|c|c|c|c|}
\hline \multirow{3}{*}{ Species } & $\mathrm{F}$ & \multicolumn{14}{|c|}{ CA } & \multirow[t]{2}{*}{ References } \\
\hline & A & A & $\mathrm{B}$ & $\mathrm{C}$ & $\mathrm{D}$ & $E$ & $\mathrm{~F}$ & $\mathrm{G}$ & $\mathrm{H}$ & I & $\mathrm{J}$ & $\mathrm{K}$ & $\mathrm{L}$ & $M$ & $\mathrm{~N}$ & \\
\hline & $\begin{array}{l}\mathrm{K} \\
\mathrm{K}\end{array}$ & K & $\mathrm{K}$ & K & $P$ & $P$ & $P$ & K & & K & $P$ & $\begin{array}{ll}P \\
P\end{array}$ & $P$ & & & Gödecke et al. (2009) \\
\hline \multirow{9}{*}{ A. racemosa } & & & & & & & & & & & & & & & & Kruse et al. (1999) \\
\hline & & & & & & & & & & & & & & & & Löser et al. (2000) \\
\hline & & & & & & & & & & & & & & & & Li et al. (2003) \\
\hline & & & & & & & & & & & & & & & & Fabricant et al. (2005) \\
\hline & & & & & & & & & & & & & & & & Stromeier et al. (2005) \\
\hline & & & & & & & & & & & & & & & & Nuntanakorn et al. (2006) \\
\hline & & & & & & & & & & & & & & & & Nuntanakorn et al. (2007) \\
\hline & & & & & & & & & & & & & & & & Gödecke et al. (2009) \\
\hline & & & & & & & & & & & & & & & & Fabricant et al. (2005) \\
\hline \multirow{4}{*}{ A. simplex } & & & & & & & & & & & & & & & & Takahira et al. (1998b) \\
\hline & & $\mathrm{m}$ & $\mathrm{m}$ & & & $\mathrm{m}$ & $\mathrm{m}$ & & & & & & & & & Takahira et al. (1998a) \\
\hline & & & & & & & & & & & & & & & & Kusano (2001) \\
\hline & & & & & & & & & & & & & & & & Iwanaga et al. (2010b) \\
\hline \multirow{2}{*}{ A. japonica } & & & & & & & & & & & & & & & & Kusano (2001) \\
\hline & & & & & & & & & & & & & & & & Iwanaga et al. (2010b) \\
\hline A. rubra & & & & & & & & & & & & & & & & \multirow{3}{*}{ Nuntanakorn et al. (2007) } \\
\hline A. pachypoda & & & & & & & & & & & & & & & & \\
\hline A. podocarpa & & & & & & & & & & & & & & & & \\
\hline $\begin{array}{l}\text { A. dahurica }+ \\
\text { A. heracleifolia }\end{array}$ & & & & & & & & & & & & & & & & Iwanaga et al. (2010a) \\
\hline \multirow{2}{*}{ A. heracleifolia } & & & & & & & & & & & & & & & & Yim et al. (2012a) \\
\hline & & & & & & & & & & & & & & & & \multirow{4}{*}{ Kusano (2001) } \\
\hline A. foetida & & & & & & & & & & & & & & & & \\
\hline A. acerina & & & & & & & & & & & & & & & & \\
\hline \multirow{3}{*}{ A. dahurica } & & & & & & & & & & & & & & & & \\
\hline & & & & & & & & & & & & & & & & Yu et al. (2019) \\
\hline & & & & & & $\mathrm{m}$ & $\mathrm{m}$ & & & & & & & & & Qin et al. (2017) \\
\hline \multirow[t]{2}{*}{$\begin{array}{l}\text { Petasites } \\
\text { japonicus }\end{array}$} & & & & & & & & & & & & & & & & $\begin{array}{l}\text { Sakamura et al. (1969, } \\
1973)\end{array}$ \\
\hline & & & & & & & & & & & & & & & & Lee et al. (2019) \\
\hline $\begin{array}{l}\text { Platycodon } \\
\text { grandiflorum }\end{array}$ & & & & & & & & & & & & & & & & Wang et al. (2017a) \\
\hline Prunus persica & & & & & & & & & & & & & & & & Kwak et al. (2018) \\
\hline
\end{tabular}

$m$ the respective cimicifugic acids were isolated as 1-methylester

The different relative amounts of single fukinolic acid and cimicifugic acids has often been used to discriminate between different Actaea species. Geng et al. (2019) investigated quality control of roots/ rhizomes material to distinguish between five Actaea species. The analysis was established by the comparison of HCAA (hydroxycinnamic acid amides) and HCAE (hydroxycinnamic acid esters) on the basis of UV and MRM (mass spectrometry with multiple reaction monitoring) profiles. A. dahurica was characterized by high amounts of isoferulic acid, cimicifugic acid B and cimicifugic acid F. A. foetida also exhibited high amounts of cimicifugic acid B and F, whereas the amount of isoferulic acid, cimicifugic acid $A$, cimicifugic acid $E$ and fukinolic acid was less intense. The spectrum of A. pachypoda showed strong peaks of fukinolic acid and cimicifugic acid A. Additionally, A. pachypoda is characterized by the clear appearance of cimicifugic acid $\mathrm{E}$ and ferulic acid. In contrast $A$. podocarpa exhibited high amounts of cimicifugic acid A followed by cimicifugic acid E. A. racemosa showed high amounts of fukinolic acid, cimicifugic acid A and B. In comparison, the intensity of cimicifugic acid $\mathrm{E}$ and $\mathrm{F}$, isoferulic acid and ferulic acid was low. In conclusion, the differentiation of Actaea species has been more specific by mass spectrometry (HCAA-analysis) than by UV (HCAEanalysis).

He et al. (2006) postulated to use the difference of cimicifugic acid levels to identify roots/rhizomes of ten Actaea species. The analysis by HPLC and the different absorption maxima are hints for the 
identification of Actaea species. All three investigated acids, namely cimicifugic acid A (326-329 nm), B (326-329 nm) and fukinolic acid $(330 \mathrm{~nm})$ were present in A. racemosa, A. dahurica and A. japonica. In contrast, $A$. biternat, $A$. foetida and $A$. heracleifolia contained none of the hydroxycinnamic acid esters. A combination of the presence of cimicifugic acid A and fukinolic acid was detected in A. rubifolia, A. acerina and A. simplex. Strikingly, A. americana showed none of these compounds.

Further investigations on the characterization of caffeic acid derivatives by LC/MS/MS were performed by Li et al. (2003). A gradient of water with $0.05 \%$ acetic acid and acetonitrile with $0.05 \%$ acetic acid has been used with different conditions at a constant flow rate of $1.6 \mathrm{ml} / \mathrm{min}$. The retention times of cimicifugic acid A and B were $21.9 \mathrm{~min}$ and $22.7 \mathrm{~min}$. The detection by MS/MS showed a peak with $m / z, 447$ (cimicifugic acid A/B) and $m / z, 253$ (loss of (iso-)ferulic acid). Fukinolic acid eluted at $16.7 \mathrm{~min}$ and was characterized by a mass of $\mathrm{m} / \mathrm{z}$ 433. The identification of fukinolic acid and cimicifugic acids $\mathrm{A} / \mathrm{B}$ was done using standards, whereas cimicifugic acids $E$ and $F$ were characterized by the comparison of fragmentation patterns.

Bittner et al. (2016) tested 208 samples of roots and rhizomes of Actaea species, most of them belonging to A. racemosa (157 samples). Further 46 samples came from other Actaea species, namely A. cimicifuga (13), A. cordifolia (10), A. simplex (11), A. dahurica (3), A. heracleifolia (3), unknown Actaea species (6) and additionally five common black cohosh samples. Fukinolic acid and five cimicifugic acids A-F were analyzed by RP-PDA-HPLC. The dry and ground plant material $(400 \mathrm{mg})$ was repetitively extracted in an ultrasonic bath with $5 \mathrm{ml} 70 \%$ methanol. After three extraction steps $>99 \%$ of the phenolic acids were extracted and this was considered a quantitative extraction. The relative amounts of various fukinolic and cimicifugic acids (determined as caffeic acid equivalents) were used to identify different Actaea species and discriminate between them. Table 3 shows that the relative amounts differ from species to species and might be useful to identify various Actaea species and adulterations of commercial drugs.

The extraction of hydroxycinnamic acid esters from A. racemosa roots and rhizomes has further been investigated by Burdette et al. (2002). A two-step extraction protocol was performed, resulting in a methanolic extract (A, $1250 \mathrm{~g})$ and a methanol $/ \mathrm{H}_{2} \mathrm{O}$ (6:4) extract (B, $112 \mathrm{~g})$. The cimicifugic acid containing extract (B) was further purified by successive HPLC steps. Calculated from the methanol extract, the yields were $0.001 \%(12.5 \mathrm{mg}), 0.0008 \%(10 \mathrm{mg})$, $0.005 \%(62.5 \mathrm{mg})$ and $0.0008 \%(10 \mathrm{mg})$ for fukinolic acid, cimicifugic acid $\mathrm{A}, \mathrm{B}$ and $\mathrm{F}$.

Callus cultures of Actaea racemosa have been established for in vitro plant regeneration (Lata et al. 2002). Callus induction was best using MS medium (Murashige and Skoog 1962) supplemented with $1.0 \mathrm{mM}$ naphthalene acetic acid (NAA) and $0.5 \mathrm{mM}$ thidiazuron (TDZ). Changing the hormone composition to 2.0 or $4.0 \mu \mathrm{M} \mathrm{TDZ}$ led to shoot regeneration and the shoots could be rooted on media containing different auxins at 2.5 and $5.0 \mu \mathrm{M}$. Addition of activated charcoal was essential for successful rooting. The regenerated plant material, however, was not analyzed for hydroxycinnamic acid esters.

\section{Biological activities of fukinolic acid and cimicifugic acids}

Cimicifugic acids and fukinolic acid are generally regarded as minor compounds with respect to the therapeutic use of the respective plants (Actaea and Petasites species) and their extracts. Mostly, the bioactivity assays aim at evaluating the effects of triterpenoids for Actaea extracts or sesquiterpenes for Petasites extracts. For the genus Cimicifuga/Actaea this has been recently reviewed by Guo et al. (2017) and Salari et al. (2021). A review concerning the use of Petasites species as medicinal plants has been published by Aydin et al. (2013). Thus, although there is a variety of effective specialized compounds present in Actaea (Cimicifuga) and Petasites species, the aim of this review is to focus on the hydroxycinnamic acid esters. The species named in the following are named according to the respective literature, explaining the mixed usage of the genus names Actaea and Cimicifuga. The biological activities of fukinolic acid and cimicifugic acids are described in more detail in the following and are summarized in Table 4.

Anti-inflammatory activities

Neutrophil elastase (EC 3.4.21.37) is an important enzyme participating in inflammatory reactions. It is 
Table 3 Relative mean amounts of different fukinolic and cimicifugic acids in six different Actaea species

\begin{tabular}{|l|l|l|l|l|l|l|}
\hline \multirow{2}{*}{ Species } & \multicolumn{7}{|l|}{} \\
\hline Actaea racemosa & FA & CA B & CA A & CA E & CA F & CA D \\
\hline Actaea cimicifuga & CA A & FA & CA E & CA D & CA B & \\
\hline Actaea cordifolia & FA & CA A & CA D & CA E & CA B & CA F \\
\hline Actaea dahurica & CA F & CA B & CA D & CA E & FA & CA A \\
\hline Actaea heracleifolia & CA F & CA B & CA E & CA D & CA A & FA \\
\hline Actaea simplex & FA & CA D & CA A & CA E & CA B & CA F \\
\hline
\end{tabular}

$F A$ fukinolic acid, $C A$ cimicifugic acid (data from Bittner et al. 2016)

active in the destruction of the basement membrane and usually shows elevated plasma levels during active inflammation (Löser et al. 2000). Fukinolic acid and cimicifugic acids have been isolated from C. racemosa rhizomes. Löser et al. (2000) described the dose-dependent inactivation of a human leukocyte elastase by fukinolic acid, consequently possessing anti-inflammatory effects. Furthermore, the esterification seemed to make fukinolic acid $\left(\mathrm{IC}_{50}=0.23 \mu \mathrm{M}\right)$ a stronger inhibitor of the active site of neutrophil elastase than caffeic acid $\left(\mathrm{IC}_{50}=93 \mu \mathrm{M}\right.$; Melzig et al. 1999). The authors suggested that this might be due to the better interaction of the ester with the more lipophilic active site of the enzyme. Additionally, cimicifugic acids $\mathrm{A} \quad\left(\mathrm{IC}_{50}=2.2 \mu \mathrm{M}\right), \quad \mathrm{B} \quad\left(\mathrm{IC}_{50}=\right.$ $11.4 \mu \mathrm{M}), \mathrm{E}\left(\mathrm{IC}_{50}>50 \mu \mathrm{M}\right)$ and $\mathrm{F}\left(\mathrm{IC}_{50}=18 \mu \mathrm{M}\right)$ successfully interacted with this enzyme, although cimicifugic acid $\mathrm{E}$ turned out to be a weak inhibitor (Löser et al. 2000). Even weaker was the selective peptidic elastase inhibitor elastatinal with an $\mathrm{IC}_{50}$ of $1150 \mu \mathrm{M}$ which was used as positive control. Docking simulation was used to determine the possible binding site of fukinolic acid to human neutrophil elastase, but the site could not be determined exactly (Steinbrecher et al. 2006). Previously, elastase inhibition combined with docking studies revealed a caffeic acid moiety coupled to a lipophilic residue as prerequisite for good binding to human leukocyte elastase (Siedle et al. 2003).

Wang et al. (2017b) established a system using mice with Pseudomonas aeruginosa-caused pneumonia to evaluate anti-inflammatory effects of components of Cimicifugae rhizoma extracts. The whole extract exerted a dose-dependent anti-inflammatory effect. TNF- $\alpha$-induced activation of NF- $\kappa \mathrm{B}$ could be reduced by more than $50 \%$ (compared to appr. $80 \%$ for dexacortal as positive control) by components of the extract, namely caffeic acid, ferulic acid/isoferulic acid, fukinolic acid and cimicifugic acids $\mathrm{C} / \mathrm{D}, \mathrm{A} / \mathrm{B}$ and $\mathrm{E}$.

Cimicifugic acid D was identified as another antiinflammatory ingredient in P. japonicus (Lee et al. 2019). Lipopolysaccharide (LPS)-stimulated macrophages were analyzed for their production of the inflammatory mediators $\mathrm{NO}$ and prostaglandin $\mathrm{E}_{2}$ $\left(\mathrm{PGE}_{2}\right)$. Additionally, iNOS (inducible nitric oxide synthase) and cyclooxygenase-2 (COX-2; prostaglandin synthase) were investigated on the basis of their expression levels. Cimicifugic acid D showed antiinflammatory effects inhibiting the synthesis of nitric oxide $\left(\mathrm{NO} ; \mathrm{IC}_{50}=12 \mu \mathrm{M}\right)$ and $\mathrm{PGE}_{2}\left(\mathrm{IC}_{50}=43 \mu \mathrm{M}\right)$ in LPS-induced macrophages, whereas caffeic acid and fukinolic acid were inactive $\left(\mathrm{IC}_{50}>50 \mu \mathrm{M}\right)$ in this assay (caffeic acid: $\mathrm{IC}_{50}>50 \mu \mathrm{M}$ for $\mathrm{NO}$, $\mathrm{IC}_{50}=45.7 \mu \mathrm{M}$ for $\mathrm{PGE}_{2}$ ). Molecular docking analyses revealed a strong affinity of cimicifugic acid D for iNOS and COX-2, explaining the inhibition of NO and $\mathrm{PGE}_{2}$ synthesis. The expression levels for both proteins, however, were not increased.

\section{Antioxidant activities}

During metabolic processes, a series of reactive oxygen species (ROS) is formed in vivo having toxic properties on various metabolic processes including DNA integrity. In cells, a variety of counteracting mechanisms are present including antioxidant compounds, repair and exchange mechanisms. The bioactivity of several hydroxycinnamic acid esters isolated from $A$. racemosa rhizomes/roots has been elucidated. Fukinolic acid and cimicifugic acid A, B and F were found to act as antioxidants in a 1,1-diphenyl-2picrylhydrazyl (DPPH) free-radical assay (Burdette et al. 2002). In conclusion, these antioxidant agents 
Table 4 Summary of biological activities of fukinolic acid and cimicifugic acids with effective concentrations and information on the applied test system

\begin{tabular}{|c|c|c|c|c|}
\hline Compound & Biological effect & Further information & $\begin{array}{l}\text { Inhibitory } \\
\text { concentration }\end{array}$ & References \\
\hline \multirow[t]{26}{*}{$\begin{array}{l}\text { Fukinolic } \\
\text { acid }\end{array}$} & \multirow[t]{4}{*}{ Anti-inflammatory } & $\begin{array}{l}\text { Inhibition of neutrophil elastase } \\
\text { (human leukocyte elastase) }\end{array}$ & $\mathrm{IC}_{50}=0.23 \mu \mathrm{M}$ & Löser et al. (2000) \\
\hline & & $\begin{array}{l}\text { Not active }\left(\mathrm{IC}_{50}>50 \mu \mathrm{M}\right) \\
\text { towards NO-formation }\end{array}$ & $\mathrm{IC}_{50}>50 \mu \mathrm{M}$ & Lee et al. (2019) \\
\hline & & $\begin{array}{l}\text { Not active }\left(\mathrm{IC}_{50}>50 \mu \mathrm{M}\right) \\
\text { towards synthesis of } \mathrm{PGE}_{2}\end{array}$ & $\mathrm{IC}_{50}>50 \mu \mathrm{M}$ & \\
\hline & & $\begin{array}{l}\text { Suppression of TNF- } \alpha \text {-induced } \\
\text { NF- } \kappa B \text { activation }\end{array}$ & No value given & Wang et al. (2017b) \\
\hline & \multirow[t]{11}{*}{ Antioxidant } & $\begin{array}{l}\text { Inhibition of lipopolysaccharide- } \\
\text { stimulated NO production }\end{array}$ & $\mathrm{IC}_{50}=0.30 \mathrm{mM}$ & Watanabe et al. (2007) \\
\hline & & $\begin{array}{l}\text { Reduction of intracellular iNOS } \\
\text { (inducible NO synthase) }\end{array}$ & $\mathrm{IC}_{50}=0.3-0.6 \mathrm{mM}$ & \\
\hline & & Reduction of iNOS mRNA level & No value given & \\
\hline & & NO radical scavenging activity & $\mathrm{IC}_{50} \geq 20 \mu \mathrm{M}$ & \\
\hline & & $\mathrm{O}_{2}^{-}$scavenging activity & $\mathrm{IC}_{50}=0.83 \mu \mathrm{M}$ & \\
\hline & & $\mathrm{OH}^{\bullet}$ radical scavenging activity & $\mathrm{IC}_{50}=1.01 \mathrm{mM}$ & \\
\hline & & \multirow[t]{4}{*}{ DPPH radical scavenging activity } & $\mathrm{IC}_{50}=20.2 \mu \mathrm{M}$ & \\
\hline & & & $\mathrm{IC}_{50}=23 \mu \mathrm{M}$ & Nuntanakorn et al. (2006) \\
\hline & & & $\mathrm{IC}_{50}=12.9 \mu \mathrm{M}$ & Nuntanakorn et al. (2007) \\
\hline & & & $\mathrm{IC}_{50}=14.1 \mu \mathrm{M}$ & Burdette et al. (2002) \\
\hline & & $\begin{array}{l}20 \% \text { inhibition of menadione- } \\
\text { induced DNA strand breakage } \\
\text { (MDA-MB-231 breast cancer } \\
\text { cell line) }\end{array}$ & At $0.46 \mu \mathrm{M}$ & \\
\hline & Antiviral & $\begin{array}{l}\text { Antiviral activities (human } \\
\text { enterovirus EV-A71) }\end{array}$ & $\mathrm{IC}_{50}=9.9 \mathrm{nM}$ & Ma et al. (2019) \\
\hline & \multirow[t]{3}{*}{$\begin{array}{l}\text { Cytotoxicity and } \\
\text { anti-tumor }\end{array}$} & $\begin{array}{l}\text { No cytotoxicity at } 115.1 \mathrm{nM} \\
\text { (human virus-infected } \\
\text { rhabdomyosarcoma cell line) }\end{array}$ & $115.1 \mathrm{nM}$ & \\
\hline & & $\begin{array}{l}\text { No detection of cytotoxic effects in } \\
\text { S30 cells }\end{array}$ & At $0.46 \mu \mathrm{M}$ & Burdette et al. (2002) \\
\hline & & $\begin{array}{l}\text { Anti-cancer efficacy on MDA- } \\
\text { MB-453 breast cancer cells }\end{array}$ & $\mathrm{IC}_{50}=0.21 \mu \mathrm{M}$ & Jiang et al. $2008 b$ \\
\hline & $\begin{array}{l}\text { Inhibition of Cyt. } \\
\text { P450 }\end{array}$ & $\begin{array}{l}\text { inhibition of CYP 1A2, 2D6, 2C9, } \\
\text { 3A4 }\end{array}$ & $\mathrm{IC}_{50}=1.8-7.1 \mu \mathrm{M}^{*}$ & Huang et al. (2010) \\
\hline & Estrogenic activity & $\begin{array}{l}126.3 \% \text { increase of proliferation in } \\
\text { estrogen-dependent MCF-7 cell } \\
\text { line }\end{array}$ & At $50 \mathrm{nM}$ & Kruse et al. (1999) \\
\hline & Hyaluronidase & $\begin{array}{l}\text { Strong }(<200 \mu \mathrm{M}) \text { inhibition of } \\
\text { hyaluronidase }\end{array}$ & $\mathrm{IC}_{50}=144 \mu \mathrm{M}$ & Iwanaga et al. (2010a, b) \\
\hline & Vasoactivity & $\begin{array}{l}\text { Vasorelaxation on norepinephrine- } \\
\text { treated rat aortic strips }\end{array}$ & At $300 \mu \mathrm{M}$ & Noguchi et al. (1998) \\
\hline & $\begin{array}{l}\text { Promotion of } \\
\text { wound-healing }\end{array}$ & $51 \%$ inhibition of collagenase & $\begin{array}{l}\text { With } 100 \mu \mathrm{g} \text { (appr. } \\
\left.0.23 \mu \mathrm{M}^{* *}\right)\end{array}$ & Kusano et al. (2001) \\
\hline & seed germination & inhibition of $\alpha$-amylase & $\mathrm{IC}_{50}=40 \mu \mathrm{M}$ & Kusano et al. (1998) \\
\hline & & Inhibition of carboxypeptidase A & $\mathrm{IC}_{50}=173 \mu \mathrm{M}$ & \\
\hline
\end{tabular}


Table 4 continued

\begin{tabular}{|c|c|c|c|c|}
\hline Compound & Biological effect & Further information & $\begin{array}{l}\text { Inhibitory } \\
\text { concentration }\end{array}$ & References \\
\hline & $\begin{array}{l}\text { Miscellaneous } \\
\text { effects }\end{array}$ & $\begin{array}{l}\text { suppression of type I allergic } \\
\text { reactions }\end{array}$ & $\mathrm{IC}_{50}=4.8 \mu \mathrm{M}$ & Shimoda et al. (2006) \\
\hline \multirow[t]{17}{*}{$\begin{array}{l}\text { Cimicifugic } \\
\text { acid A }\end{array}$} & \multirow[t]{2}{*}{ Anti-inflammatory } & $\begin{array}{l}\text { Inhibition of neutrophil elastase } \\
\text { (human leukocyte elastase) }\end{array}$ & $\mathrm{IC}_{50}=2.2 \mu \mathrm{M}$ & Löser et al. (2000) \\
\hline & & $\begin{array}{l}\text { Suppression of TNF- } \alpha \text {-induced } \\
\text { NF- } \kappa \text { B activation }\end{array}$ & No value given & Wang et al. (2017b) \\
\hline & \multirow[t]{3}{*}{ Antioxidant } & \multirow[t]{3}{*}{ DPPH radical scavenging activity } & $\mathrm{IC}_{50}=27.7 \mu \mathrm{M}$ & Burdette et al. (2002) \\
\hline & & & $\mathrm{IC}_{50}=12 \mu \mathrm{M}$ & Nuntanakorn et al. (2006) \\
\hline & & & $\mathrm{IC}_{50}=21.9 \mu \mathrm{M}$ & Nuntanakorn et al. (2007) \\
\hline & \multirow[t]{2}{*}{ Antiviral } & $\begin{array}{l}\text { Antiviral activities (human } \\
\text { enterovirus EV-A71) }\end{array}$ & $\mathrm{IC}_{50}=47.5 \mathrm{nM}$ & \multirow[t]{2}{*}{ Ma et al. (2019) } \\
\hline & & inhibition of EV-A71 replication & $\mathrm{IC}_{50}=223.0 \mathrm{nM}$ & \\
\hline & \multirow[t]{4}{*}{$\begin{array}{l}\text { Cytotoxicity and } \\
\text { anti-tumor }\end{array}$} & $\begin{array}{l}\text { Influence of critical apoptosis } \\
\text { marker PARP }\end{array}$ & $\mathrm{IC}_{50}=15.38 \mu \mathrm{M}$ & Yim et al. (2012b) \\
\hline & & $\begin{array}{l}\text { No detection of cytotoxic effects in } \\
\text { S30 cells }\end{array}$ & At $0.45 \mu \mathrm{M}$ & Burdette et al. (2002) \\
\hline & & $\begin{array}{l}\text { Anti-cancer efficacy on MDA- } \\
\text { MB-453 breast cancer cells }\end{array}$ & $\mathrm{IC}_{50}=0.17 \mu \mathrm{M}$ & Jiang et al. 2008b \\
\hline & & $\begin{array}{l}\text { cleavage of apoptosis marker } \\
\text { PARP }\end{array}$ & At $20 \mu \mathrm{M}$ & Yim et al. (2012b) \\
\hline & $\begin{array}{l}\text { Inhibition of Cyt. } \\
\text { P450 }\end{array}$ & $\begin{array}{l}\text { Inhibition of CYP 1A2, 2D6, 2C9, } \\
\text { 3A4 }\end{array}$ & $\mathrm{IC}_{50}=7.2-9.7 \mu \mathrm{M}^{*}$ & Huang et al. (2010) \\
\hline & Hyaluronidase & $\begin{array}{l}\text { Strong }(<200 \mu \mathrm{M}) \text { inhibition of } \\
\text { hyaluronidase }\end{array}$ & $\mathrm{IC}_{50}=112 \mu \mathrm{M}$ & Iwanaga et al. $(2010 a, b)$ \\
\hline & $\begin{array}{l}\text { Promotion of } \\
\text { wound-healing }\end{array}$ & $47 \%$ inhibition of collagenase & $\begin{array}{l}\text { With } 100 \mu \mathrm{g} \text { (appr. } \\
\left.0.23 \mu \mathrm{M}^{* *}\right)\end{array}$ & Kusano et al. (2001) \\
\hline & Seed germination & Inhibition of $\alpha$-amylase & $\mathrm{IC}_{50}=24.1 \mu \mathrm{M}$ & Kusano et al. (1998) \\
\hline & & Inhibition of carboxypeptidase A & $\mathrm{IC}_{50}=198 \mu \mathrm{M}$ & \\
\hline & $\begin{array}{l}\text { Miscellaneous } \\
\text { effects }\end{array}$ & $\begin{array}{l}\text { Influence on serotonin } 5 \mathrm{HT}_{7} \\
\text { receptor }\end{array}$ & $\mathrm{IC}_{50}=120 \mu \mathrm{M}$ & Farnsworth et al. (2008) \\
\hline \multirow[t]{10}{*}{$\begin{array}{l}\text { Cimicifugic } \\
\text { acid B }\end{array}$} & \multirow[t]{2}{*}{ Anti-inflammatory } & $\begin{array}{l}\text { Inhibition of neutrophil elastase } \\
\text { (human leukocyte elastase) }\end{array}$ & $\mathrm{IC}_{50}=11.4 \mu \mathrm{M}$ & Löser et al. (2000) \\
\hline & & $\begin{array}{l}\text { Suppression of TNF- } \alpha \text {-induced } \\
\text { NF- } \kappa B \text { activation }\end{array}$ & No value given & Wang et al. (2017b) \\
\hline & \multirow[t]{3}{*}{ Antioxidant } & \multirow[t]{3}{*}{ DPPH radical scavenging activity } & $\mathrm{IC}_{50}=22.9 \mu \mathrm{M}$ & Burdette et al. (2002) \\
\hline & & & $\mathrm{IC}_{50}=21 \mu \mathrm{M}$ & Nuntanakorn et al. (2006) \\
\hline & & & $\mathrm{IC}_{50}=23.1 \mu \mathrm{M}$ & Nuntanakorn et al. (2007) \\
\hline & \multirow[t]{2}{*}{ Antiviral } & $\begin{array}{l}\text { ATP-docking results against } \\
\text { dengue virus components }\end{array}$ & $-143.5 \mathrm{~kJ} / \mathrm{mol}$ & Powers and Setzer (2016) \\
\hline & & $\begin{array}{l}\text { RNA-docking results against } \\
\text { dengue virus components }\end{array}$ & $-117.8 \mathrm{~kJ} / \mathrm{mol}$ & \\
\hline & \multirow[t]{3}{*}{$\begin{array}{l}\text { Cytotoxicity and } \\
\text { anti-tumor }\end{array}$} & $\begin{array}{l}\text { Influence of critical apoptosis } \\
\text { marker PARP }\end{array}$ & $\mathrm{IC}_{50}=12.42 \mu \mathrm{M}$ & Yim et al. (2012b) \\
\hline & & $\begin{array}{l}\text { No detection of cytotoxic effects in } \\
\text { S30 cells }\end{array}$ & At $0.45 \mu \mathrm{M}$ & Burdette et al. (2002) \\
\hline & & $\begin{array}{l}\text { Anti-cancer efficacy on MDA- } \\
\text { MB-453 breast cancer cells }\end{array}$ & $\mathrm{IC}_{50}=0.37 \mu \mathrm{M}$ & Jiang et al. 2008b \\
\hline
\end{tabular}


Table 4 continued

\begin{tabular}{|c|c|c|c|c|}
\hline Compound & Biological effect & Further information & $\begin{array}{l}\text { Inhibitory } \\
\text { concentration }\end{array}$ & References \\
\hline & & $\begin{array}{l}\text { Cleavage of apoptosis marker } \\
\text { PARP }\end{array}$ & $20 \mu \mathrm{M}$ & Yim et al. (2012b) \\
\hline & $\begin{array}{l}\text { Inhibition of Cyt. } \\
\text { P450 }\end{array}$ & $\begin{array}{l}\text { Inhibition of CYP 1A2, 2D6, 2C9, } \\
\text { 3A4 }\end{array}$ & $\mathrm{IC}_{50}=7.35-12.6 \mu \mathrm{M}^{*}$ & Huang et al. (2010) \\
\hline & Hyaluronidase & $\begin{array}{l}\text { Strong }(<200 \mu \mathrm{M}) \text { inhibition of } \\
\text { hyaluronidase }\end{array}$ & $\mathrm{IC}_{50}=82 \mu \mathrm{M}$ & Iwanaga et al. (2010a, b) \\
\hline & $\begin{array}{l}\text { Promotion of } \\
\text { wound-healing }\end{array}$ & $64 \%$ inhibition of collagenase & $\begin{array}{l}\text { With } 100 \mu \mathrm{g} \text { (appr. } \\
\left.0.23 \mu \mathrm{M}^{* *}\right)\end{array}$ & Kusano et al. (2001) \\
\hline & $\begin{array}{l}\text { Miscellaneous } \\
\text { effects }\end{array}$ & $\begin{array}{l}\text { Influence on serotonin } 5 \mathrm{HT}_{7} \\
\text { receptor }\end{array}$ & $\mathrm{IC}_{50}=2.67 \mu \mathrm{M}$ & Farnsworth et al. (2008) \\
\hline \multirow[t]{4}{*}{$\begin{array}{l}\text { Cimicifugic } \\
\text { acid } \mathrm{C}\end{array}$} & Anti-inflammatory & $\begin{array}{l}\text { Suppression of TNF- } \alpha \text {-induced } \\
\text { NF- } \kappa B \text { activation }\end{array}$ & No value given & Wang et al. (2017b) \\
\hline & Hyaluronidase & Inhibition of hyaluronidase & $\mathrm{IC}_{50}=251 \mu \mathrm{M}$ & Iwanaga et al. (2010a, b) \\
\hline & Vasoactivity & $\begin{array}{l}\text { Vasocontraction on } \\
\text { norepinephrine-treated rat aortic } \\
\text { strips }\end{array}$ & At $300 \mu \mathrm{M}$ & Noguchi et al. (1998) \\
\hline & $\begin{array}{l}\text { Wound-healing } \\
\text { promotion }\end{array}$ & $47 \%$ inhibition of collagenase & $\begin{array}{l}\text { With } 100 \mu \mathrm{g} \text { (appr. } \\
\left.0.23 \mu \mathrm{M}^{* *}\right)\end{array}$ & Kusano et al. (2001) \\
\hline \multirow{8}{*}{$\begin{array}{l}\text { Cimicifugic } \\
\text { acid D }\end{array}$} & Anti-inflammatory & Inhibition of NO-formation & $\mathrm{IC}_{50}=12 \mu \mathrm{M}$ & Lee et al. (2019) \\
\hline & & Inhibition of $\mathrm{PGE}_{2}$-synthesis & $\mathrm{IC}_{50}=43 \mu \mathrm{M}$ & \\
\hline & & $\begin{array}{l}\text { Influence on NO-formation and } \\
\text { PGE }_{2} \text { production is explained by } \\
\text { a strong affinity of cimicifugic } \\
\text { acid D towards iNOS and COX-2 } \\
\text { in docking studies }\end{array}$ & $\begin{array}{l}-\log \\
\quad(\mathrm{FBE})=-10 \mathrm{kcal} / \mathrm{mol} \\
(\mathrm{iNOS})\end{array}$ & \\
\hline & & & $\begin{array}{l}-\log \\
(\mathrm{FBE})=-8.3 \mathrm{kcal} / \mathrm{mol} \\
(\mathrm{COX} 2)\end{array}$ & \\
\hline & & $\begin{array}{l}\text { Suppression of TNF- } \alpha \text {-induced } \\
\text { NF- } \kappa \text { B activation }\end{array}$ & No value given & Wang et al. (2017b) \\
\hline & Hyaluronidase & $\begin{array}{l}\text { strong }(<200 \mu \mathrm{M}) \text { inhibition of } \\
\text { hyaluronidase }\end{array}$ & $\mathrm{IC}_{50}=153 \mu \mathrm{M}$ & Iwanaga et al. $(2010 a, b)$ \\
\hline & Vasoactivity & $\begin{array}{l}\text { Vasorelaxation on norepinephrine- } \\
\text { treated rat aortic strips }\end{array}$ & At $300 \mu \mathrm{M}$ & Noguchi et al. (1998) \\
\hline & $\begin{array}{l}\text { Promotion of } \\
\text { wound-healing }\end{array}$ & $20 \%$ inhibition of collagenase & $\begin{array}{l}\text { With } 100 \mu \mathrm{g} \text { (appr. } \\
\left.0.23 \mu \mathrm{M}^{* *}\right)\end{array}$ & Kusano et al. (2001) \\
\hline \multirow[t]{5}{*}{$\begin{array}{l}\text { Cimcifugic } \\
\text { acid E }\end{array}$} & Anti-inflammatory & $\begin{array}{l}\text { Inhibition of neutrophil elastase } \\
\text { (human leukocyte elastase) }\end{array}$ & $\mathrm{IC}_{50}>50 \mu \mathrm{M}$ & Löser et al. (2000) \\
\hline & & $\begin{array}{l}\text { Suppression of TNF- } \alpha \text {-induced } \\
\text { NF- } \kappa \text { B activation }\end{array}$ & No value given & Wang et al. (2017b) \\
\hline & Antioxidant & DPPH radical scavenging activity & $\mathrm{IC}_{50}=65.5 \mu \mathrm{M}$ & Nuntanakorn et al. (2007) \\
\hline & Hyaluronidase & $\begin{array}{l}\text { Strong }(<200 \mu \mathrm{M}) \text { inhibition of } \\
\text { hyaluronidase }\end{array}$ & $\mathrm{IC}_{50}=120 \mu \mathrm{M}$ & Iwanaga et al. $(2010 a, b)$ \\
\hline & $\begin{array}{l}\text { Promotion of } \\
\text { wound-healing }\end{array}$ & $26 \%$ inhibition of collagenase & $\begin{array}{l}\text { With } 100 \mu \mathrm{g} \text { (appr. } \\
\left.0.23 \mu \mathrm{M}^{* *}\right)\end{array}$ & Kusano et al. (2001) \\
\hline \multirow[t]{2}{*}{$\begin{array}{l}\text { Cimicifugic } \\
\text { acid F }\end{array}$} & Anti-inflammatory & $\begin{array}{l}\text { Inhibition of neutrophil elastase } \\
\text { (human leukocyte elastase) }\end{array}$ & $\mathrm{IC}_{50}=18 \mu \mathrm{M}$ & Löser et al. (2000) \\
\hline & Antioxidant & DPPH radical scavenging activity & $\mathrm{IC}_{50}=20.5 \mu \mathrm{M}$ & Burdette et al. (2002) \\
\hline
\end{tabular}


Table 4 continued

\begin{tabular}{|c|c|c|c|c|}
\hline Compound & Biological effect & Further information & $\begin{array}{l}\text { Inhibitory } \\
\text { concentration }\end{array}$ & References \\
\hline & & & $\mathrm{IC}_{50}=151.5 \mu \mathrm{M}$ & Nuntanakorn et al. (2007) \\
\hline & Cytotoxicity & $\begin{array}{l}\text { No detection of cytotoxic effects in } \\
\text { S30 cells }\end{array}$ & At $0.46 \mu \mathrm{M}$ & Burdette et al. (2002) \\
\hline & Hyaluronidase & $\begin{array}{l}\text { Strong }(<200 \mu \mathrm{M}) \text { inhibition of } \\
\text { hyaluronidase }\end{array}$ & $\mathrm{IC}_{50}=92 \mu \mathrm{M}$ & Iwanaga et al. $(2010 a, b)$ \\
\hline & $\begin{array}{l}\text { Promotion of } \\
\text { wound-healing }\end{array}$ & $37 \%$ inhibition of collagenase & $\begin{array}{l}\text { With } 100 \mu \mathrm{g} \text { (appr. } \\
\left.0.23 \mu \mathrm{M}^{* *}\right)\end{array}$ & Kusano et al. (2001) \\
\hline \multirow{6}{*}{$\begin{array}{l}\text { Cimicifugic } \\
\text { acid G }\end{array}$} & Antioxidant & DPPH radical scavenging activity & $\mathrm{IC}_{50}=37 \mu \mathrm{M}$ & Nuntanakorn et al. (2006) \\
\hline & Antiviral & $\begin{array}{l}\text { ATP-docking results against } \\
\text { dengue virus components }\end{array}$ & $-141.7 \mathrm{~kJ} / \mathrm{mol}$ & Powers and Setzer (2016) \\
\hline & & $\begin{array}{l}\text { RNA-docking results against } \\
\text { dengue virus components }\end{array}$ & $-122.6 \mathrm{~kJ} / \mathrm{mol}$ & \\
\hline & Cytotoxicity & $\begin{array}{l}32 \% \text { decrease of MCF-7 cell } \\
\text { proliferation }\end{array}$ & At $30 \mu \mathrm{M}$ & Nuntanakorn et al. (2006) \\
\hline & Estrogenic activity & $\begin{array}{l}\text { 1.14-fold increase of MCF-7 cell } \\
\text { proliferation }\end{array}$ & At $10 \mu \mathrm{M}$ & \\
\hline & Hyaluronidase & $\begin{array}{l}\text { Strong }(<200 \mu \mathrm{M}) \text { inhibition of } \\
\text { hyaluronidase }\end{array}$ & $\mathrm{IC}_{50}=138 \mu \mathrm{M}$ & Iwanaga et al. (2010a, b) \\
\hline $\begin{array}{l}\text { Cimicifugic } \\
\text { acid } \mathrm{H}\end{array}$ & Hyaluronidase & Inhibition of hyaluronidase & $\mathrm{IC}_{50}=525 \mu \mathrm{M}$ & Iwanaga et al. $(2010 a, b)$ \\
\hline $\begin{array}{l}\text { Cimicifugic } \\
\text { acid I }\end{array}$ & Hyaluronidase & $\begin{array}{l}\text { Strong }(<200 \mu \mathrm{M}) \text { inhibition of } \\
\text { hyaluronidase }\end{array}$ & $\mathrm{IC}_{50}=143 \mu \mathrm{M}$ & Iwanaga et al. (2010a, b) \\
\hline \multirow[t]{3}{*}{$\begin{array}{l}\text { Cimicifugic } \\
\text { acid J }\end{array}$} & Hyaluronidase & $\begin{array}{l}\text { Strong }(<200 \mu \mathrm{M}) \text { inhibition of } \\
\text { hyaluronidase }\end{array}$ & $\mathrm{IC}_{50}=193 \mu \mathrm{M}$ & Iwanaga et al. (2010a, b) \\
\hline & Antiviral & $\begin{array}{l}\text { Antiviral activities (human } \\
\text { enterovirus EV-A71) }\end{array}$ & $\mathrm{IC}_{50}=59.9 \mathrm{nM}$ & Ma et al. (2019) \\
\hline & Cytotoxicity & Inhibition of EV-A71 replication & $\mathrm{IC}_{50}=151.4 \mathrm{nM}$ & \\
\hline $\begin{array}{l}\text { Cimicifugic } \\
\text { acid K }\end{array}$ & Hyaluronidase & Inhibition of hyaluronidase & $\mathrm{IC}_{50}=255 \mu \mathrm{M}$ & Iwanaga et al. (2010a, b) \\
\hline $\begin{array}{l}\text { Cimicifugic } \\
\text { acid L }\end{array}$ & Hyaluronidase & $\begin{array}{l}\text { Strong }(<200 \mu \mathrm{M}) \text { inhibition of } \\
\text { hyaluronidase }\end{array}$ & $\mathrm{IC}_{50}=102 \mu \mathrm{M}$ & Iwanaga et al. $(2010 a, b)$ \\
\hline $\begin{array}{l}\text { Cimicifugic } \\
\text { acid } \mathrm{M}\end{array}$ & Hyaluronidase & $\begin{array}{l}\text { Strong }(<200 \mu \mathrm{M}) \text { inhibition of } \\
\text { hyaluronidase }\end{array}$ & $\mathrm{IC}_{50}=173 \mu \mathrm{M}$ & Iwanaga et al. (2010a, b) \\
\hline $\begin{array}{l}\text { Cimicifugic } \\
\text { acid } \mathrm{N}\end{array}$ & Hyaluronidase & $\begin{array}{l}\text { Strong }(<200 \mu \mathrm{M}) \text { inhibition of } \\
\text { hyaluronidase }\end{array}$ & $\mathrm{IC}_{50}=120 \mu \mathrm{M}$ & Iwanaga et al. (2010a, b) \\
\hline
\end{tabular}

*The range of $\mathrm{IC}_{50}$ value for different CYP isoforms; **Data as given in the reference; $\mathrm{FBE}=$ free binding energy

scavenge ROS, the inhibitory concentrations detected here were $\mathrm{IC}_{50}=14.1 \mu \mathrm{M}$ for fukinolic acid and $\mathrm{IC}_{50}=27.7 \mu \mathrm{M} \quad(\mathrm{A}), \quad \mathrm{IC}_{50}=22.9 \mu \mathrm{M} \quad$ (B) and $\mathrm{IC}_{50}=20.5 \mu \mathrm{M}(\mathrm{F})$ for cimicifugic acids. In addition, fukinolic acid at $200 \mu \mathrm{g} / \mathrm{ml}(0.46 \mu \mathrm{M})$ inhibited menadione-induced DNA strand breakage in a breast cancer cell line (MDA-MB-231) by approximately $20 \%$ while caffeic acid was considerably more effective (appr. 70\% inhibition at $100 \mu \mathrm{g} / \mathrm{ml}=0.56 \mu \mathrm{M}$ ).
At the same concentration $(200 \mu \mathrm{g} / \mathrm{ml}=0.45-0.46$ $\mu \mathrm{M})$ none of the above-mentioned compounds showed signs of cytotoxicity.

A further DPPH free-radical assay elucidated the antioxidant property of cimicifugic acid $\mathrm{G}$ along with cimicifugic acids A, B and fukinolic acid (Nuntanakorn et al. 2006). Fukinolic acid and cimicifugic acids from rhizomes and roots of C. racemosa possessed the ability to scavenge radicals. The $\mathrm{IC}_{50}$ 
values were at $12 \mu \mathrm{M}$ (cimicifugic acid A), $21 \mu \mathrm{M}$ (cimicifugic acid B), $37 \mu \mathrm{M}$ (cimicifugic acid G) and $23 \mu \mathrm{M}$ (fukinolic acid) compared to gallic acid $\left(\mathrm{IC}_{50}=29.9 \mu \mathrm{M}\right)$ which was tested as positive control. The same group tested further compounds from Actaea species in DPPH free-radical assays and found $\mathrm{IC}_{50}$ values of $12.9 \mu \mathrm{M}$ (fukinolic acid), $21.9 \mu \mathrm{M}$ (cimicifugic acid A), $23.1 \mu \mathrm{M}$ (B), $65.5 \mu \mathrm{M}$ (E) and $151.5 \mu \mathrm{M}$ (F) compared to ascorbic acid $\left(\mathrm{IC}_{50}=105.5 \mu \mathrm{M}\right)$ as positive control. Piscidic acid derivatives (with only one $\mathrm{OH}$-group at the aromatic ring of the benzyltartaric acid derivative) thus turned out to be less active (Nuntanakorn et al. 2007).

Watanabe et al. (2007) tested the scavenging activity of fukinolic acid (FA; isolated from $P$. japonicus) for superoxide anions $\left(\mathrm{O}_{2}{ }^{-}\right)$, hydroxyl radicals $\left(\mathrm{OH}^{\bullet}\right), \mathrm{NO}$ radicals and DPPH radicals in comparison to chlorogenic acid (CGA), gallic acid (GA) and epigallocatechin gallate (EGCG). In all assays, FA proved to be active, but with varying relation to the other natural products. $\mathrm{O}_{2}^{-}$scavenging followed the order $\mathrm{ECGC}>\mathrm{GA}>\mathrm{FA}>\mathrm{CGA}$, while $\mathrm{OH}^{\bullet}$ scavenging was best by ECGC followed by $\mathrm{CGA}>\mathrm{FA}>$ GA. NO and DPPH scavenging were in the sequence $\mathrm{ECGC}=\mathrm{GA}>\mathrm{FA}>\mathrm{CGA}$ and $\mathrm{ECGC}>\mathrm{GA}>$ FA $>$ CGA, respectively. IC $_{50}$ values were determined for fukinolic acid at $0.83 \mu \mathrm{M}$ (for $\mathrm{O}_{2}{ }^{-}$), $1.01 \mathrm{mM} \quad\left(\mathrm{OH}^{\bullet}\right),>20 \mu \mathrm{M} \quad(\mathrm{NO}$ radicals) and $20.2 \mu \mathrm{M}$ (DPPH radicals). Furthermore, the lipopolysaccharide-stimulated NO production was measured in an immortalized mouse cell line. Here $\mathrm{FA}\left(\mathrm{IC}_{50}=0.30 \mathrm{mM}\right)$ showed a slightly better activity than CGA $\left(\mathrm{IC}_{50}=0.55 \mathrm{mM}\right)$. The concentration of iNOS was inhibited by FA $\left(\mathrm{IC}_{50}=0.3-0.6 \mathrm{mM}\right)$ while CGA was not active in this concentration range. The levels of iNOS mRNA were also more strongly reduced by FA than by CGA.

The ABTS (2,2'-azino-bis(3-ethylbenzothiazoline6-sulfonic acid)) radical scavenging assay was used to evaluate the activity of fukinolic acid in extracts from leaves and roots of $P$. japonicus in comparison to Trolox; the leaf extract showed slightly higher activity (Kim et al. 2012).

A flower bud extract of $P$. japonicus was tested for its antioxidant compounds by Hiemori-Kondo and Nii (2020). The most active compound in the DPPHradical scavenging assay was fukinolic acid (FA) followed by different caffeoylquinic acid derivatives which showed one third of the activity of FA or less.
Estrogenic activities

The estrogenic activity of fukinolic acid (at a dose range of $5 \times 10^{-7}$ to $5 \times 10^{-9} \mathrm{M}$ ) has been tested with MCF-7 breast cancer cells (Kruse et al. 1999). Fukinolic acid had been isolated from C. racemosa rhizomes before. It gave rise to an increase in cell proliferation of $126.3 \%$ at a concentration of $50 \mathrm{nM}$ in comparison to $120 \%$ for estrogen $(0.1 \mathrm{nM})$. Also, cimicifugic acid $\mathrm{G}$ isolated from A. racemosa has been classified as estrogen-effective substance by stimulating the cell proliferation of MCF-7 cells (Nuntanakorn et al. 2006). In comparison to untreated cells, cimicifugic acid $\mathrm{G}$ induced a 1.14-fold stimulation of cell proliferation at $10 \mu \mathrm{M}$. Enterolactone and estradiol were used as positive controls and showed cell growth stimulation of 1.84 -fold at $16.8 \mu \mathrm{M}$ and 3.6-fold at $3.7 \mathrm{nM}$, respectively. No estrogenic activity was, however, found by Stromeier et al. (2005) and Farnsworth et al. (2008).

\section{Antiviral effects}

An extract of rhizomes of $C$. heracleifolia was analyzed for its antiviral activity against human enterovirus EV-A71 and the total extract as well as isolated fractions containing fukinolic acid $\left(\mathrm{IC}_{50}=4.3 \mu \mathrm{g} / \mathrm{ml}=9.9 \mathrm{nM}\right)$, cimicifugic acid $\mathrm{A}$ $\left(\mathrm{IC}_{50}=21.3 \mu \mathrm{g} / \mathrm{ml}=47.5 \mathrm{nM}\right)$ and $\mathrm{J} \quad\left(\mathrm{IC}_{50}=\right.$ $27.7 \mu \mathrm{g} / \mathrm{ml}=59.9 \mathrm{nM}$ ) were identified as the active compounds inhibiting virus replication (Ma et al. 2019). The cytotoxicity of these compounds was at $115.1 \mathrm{nM}$ for fukinolic acid and $223.0 \mathrm{nM}$ and $151.4 \mathrm{nM}$ for cimicifugic acids A and J, respectively. The EV-A71 virus and other related enteroviruses cause hand-foot-and-mouth disease and in severe cases neurological disorders. Since there is currently no efficient drug and no reliable treatment of EV-A71, cimicifugic acids might be a promising therapy (Ma et al. 2019). Cimicifugic acids B and I turned out to be inactive. The authors deduced structure-activity relationships from their results. Thus, a caffeic acid substitution in the hydroxycinnamic acid part (as in fukinolic acid) is favorable and methylation of one of the $\mathrm{OH}$-groups reduced the antiviral activity. Additionally, assays testing the activity of fukinolic acid against the viral 3C peptidase showed no activity and thus virus replication is inhibited by a different mechanism. 
Computational docking studies were performed with several proteins from Dengue virus. Here, cimicifugic acids $\mathrm{B}$ and $\mathrm{G}$ showed very good docking results towards the ATP-binding site of the viral helicase (Powers and Setzer 2016). The docking energy displayed $-143.5 \mathrm{~kJ} / \mathrm{mol}$ for cimicifugic acid B and $-141.7 \mathrm{~kJ} / \mathrm{mol}$ for cimicifugic acid G. In comparison, the affinity towards the RNA site was lower with $-117.8 \mathrm{~kJ} / \mathrm{mol}$ (cimicifugic acid B) and $-122.6 \mathrm{~kJ} / \mathrm{mol}$ (cimicifugic acid $\mathrm{G}$ ).

Cytotoxicity and anti-cancer activities

Although a number of investigations has been made to clarify the cytotoxic potential of fukinolic acid and cimicifugic acids, the results are not homogenous. Hydroxycinnamic acid esters investigated by Burdette et al. (2002) did not show any cytotoxic effects at $200 \mu \mathrm{g} / \mathrm{ml}(=0.45-0.46 \mu \mathrm{M})$ in human breast cancer S30 cells. Fukinolic/cimicifugic acids analyzed by Huang et al. (2010) did not damage liver carcinoma Hep-G2 cells in concentrations up to $50 \mu \mathrm{g} / \mathrm{ml}$ $(\sim 0.12 \mu \mathrm{M})$. However, a concentration of $100 \mu \mathrm{g} /$ $\mathrm{ml}(\sim 0.23 \mu \mathrm{M})$ resulted in cell mortality of $89-100 \%$.

Nuntanakorn et al. (2006) did not detect a cytotoxic effect of cimicifugic acid $\mathrm{G}$ at $10 \mu \mathrm{M}$ in MCF-7 breast cancer cells, in contrast, cell proliferation was stimulated, but concentrations of $30 \mu \mathrm{M}$ caused cytotoxicity of $32 \%$. Furthermore, Ma et al. (2019) reported cimicifugic acids and fukinolic acid to possess cytotoxic activity at concentrations between 115.1 and $223.0 \mathrm{nM}$.

A different breast cancer cell line (MDA-MB-453) was used to evaluate the anti-cancer efficiencies of fukinolic acid and cimicifugic acids $\mathrm{A}$ and $\mathrm{B}$ with $\mathrm{IC}_{50}$ values of $90 \mu \mathrm{g} / \mathrm{ml}(0.21 \mu \mathrm{M}), 74 \mu \mathrm{g} / \mathrm{ml}(0.17 \mu \mathrm{M})$ and $165 \mu \mathrm{g} / \mathrm{ml}(0.37 \mu \mathrm{M})$, respectively (Jiang et al. 2008b).

Yim et al. (2012b) investigated the cytotoxic activities of the butanol extract of $C$. heracleifolia as well as of isolated cimicifugic acids A, B, E and F in a human colon cancer cell line (HCT116). Furthermore, the hydroxycinnamic acid esters were analyzed for their influence on the expression of a critical apoptosis marker PARP (poly(ADP ribose) polymerase), an enzyme involved in the repair of DNA single-strand breaks. Cimicifugic acid $\mathrm{A}\left(\mathrm{IC}_{50}=15.38 \mu \mathrm{M}\right)$ and $\mathrm{B}$ $\left(\mathrm{IC}_{50}=12.42 \mu \mathrm{M}\right)$ showed a dose-dependent
$(2.5-40 \mu \mathrm{M})$ anti-proliferative effect on HCT116 cells, whereas cimicifugic acids $\mathrm{E}$ and $\mathrm{F}$ and piscidic acid did not show cytotoxic effects. In Western blot analysis, cimicifugic acids A and B induced a visible increase of cleaved PARP at $20 \mu \mathrm{M}$ and $40 \mu \mathrm{M}$. The authors related the investigated activities to the fukiic acid part of the molecule, since piscidic acid derivatives were inactive.

\section{Inhibition of collagenases}

Collagens are ubiquitous in animals. They represent a family of fibrous structural proteins in the extracellular matrix of tendons, ligaments, bones, cartilage and connective tissues (Shoulders and Raines 2009). Collagenases or matrix metalloproteinases (MMP) are involved in wound healing and high levels of MMPs are related to delayed healing (TardáguilaGarcía et al. 2019). Thus, inhibition of collagenases/ MMPs would be beneficial to promote wound healing.

Kusano et al. (2001) reported an effect of cimicifugic acids A-F and fukinolic acid on collagenolytic enzymes. All tested acids inhibited collagenases, but the effect of fukinolic acid and cimicifugic acids A-C (47-64\% collagenase inhibition at $100 \mu \mathrm{g}$ per assay corresponding to $0.22-0.24 \mu \mathrm{M}$ as given by the authors) was significantly stronger than the effect of cimicifugic acids D-F (20-37\%) compared to an inhibition of $51 \%$ by rosmarinic acid (at $0.28 \mu \mathrm{M}$ ). This inhibition was dose-dependent. The collagenolytic activity of trypsin was inhibited as well. Consequently, the presence of a second hydroxyl group on the aromatic ring as in fukiic acid (the alcoholic part of cimicifugic acids $\mathrm{A}-\mathrm{C}$ and fukinolic acid) enhances the collagenolytic activity. In conclusion, extracts from Cimicifuga rhizomes might be used for therapeutic aspects due to the prevention of collagen degradation in inflammatory processes.

Inhibition of cytochrome P450 enzymes and hepatotoxicity

Cytochrome P450 enzymes (CYP) are ubiquitous in living organisms, participating in detoxification, drug metabolism as well as biosynthetic reactions (Nair et al. 2016). In order to investigate the observed hepatotoxic activity in women treated with extracts of C. racemosa, the effect of the triterpenes and the hydroxycinnamic acid esters were differentiated 
Table $5 \mathrm{IC}_{50}$ values for hyaluronidase inhibition of cimicifugic acid-related compounds (fukinolic acid = FA) from Actaea spec. against rosmarinic acid (RA) as control (values taken from Iwanaga et al. 2010a, b)

\begin{tabular}{|l|c|c|c|c|c|c|c|c|c|c|c|c|c|c|c|c|c|c|c|}
\hline & RA & FA & & \multicolumn{10}{|c|}{ Cimicifugic acid } & \multicolumn{10}{|c|}{ Shomaside } \\
\hline $\begin{array}{l}\text { Com- } \\
\text { pound }\end{array}$ & & & A & B & C & D & E & F & G & H & I & J & K & L & M & N & A & B & C \\
\hline $\begin{array}{l}\text { IC } 50 \\
{[\mu \mathrm{M}]}\end{array}$ & 545 & 144 & 112 & 82 & 251 & 153 & 120 & 92 & 138 & 525 & 143 & 193 & 255 & 102 & 173 & 120 & 573 & 430 & 663 \\
\hline
\end{tabular}

Compounds showing better hyaluronidase inhibition than RA are shaded grey

(Huang et al. 2010). Fukinolic acid and cimicifugic acids $\mathrm{A}$ and $\mathrm{B}$ were examined for their inhibitory effect towards the CYP enzymes 1A2, 2D6, 2C9 and $3 \mathrm{~A} 4$ and displayed $\mathrm{IC}_{50}$ values of 1.8-7.2 $\mu \mathrm{M}$ (fukinolic acid), 7.2-9.7 $\mu \mathrm{M}$ (cimicifugic acid $\mathrm{A}$ ) and 7.35-12.6 $\mu \mathrm{M}$ (cimicifugic acid B), respectively. Selective inhibitors of the four tested CYPs showed $\mathrm{IC}_{50}$ values in the sub-micromolar range. CYP-inhibition by the triterpene glycosides, on the other hand, was only weak $\left(\mathrm{IC}_{50}=25-100 \mu \mathrm{M}\right)$. At the same time, the growth of Hep-G2 cells (a human liver cancer cell line) was not inhibited by C. racemosa extracts up to concentrations of $50 \mu \mathrm{g} / \mathrm{ml}$ but strong cytotoxicity was shown at concentrations exceeding $100 \mu \mathrm{g} / \mathrm{ml}(89-100 \%)$.

Hyaluronidase inhibition

Hyaluronidases are used medicinally to degrade hyaluronic acid which is a component of the complex polymer of the extracellular matrix resulting in an increased diffusion and resorption (Buhren et al. 2016). Fukinolic acid, cimicifugic acids A-N as well as shomasides were tested for their hyaluronidase inhibitory activities against rosmarinic acid (RA) as control (Iwanaga et al. 2010a, b). Many of them showed lower $\mathrm{IC}_{50}$ values than RA for hyaluronidase inhibition (Table 5).

\section{Vasoactive effects}

Fukinolic acid and cimicifugic acids A-E were tested for vasoactivity with rat aortic strips pre-contracted with norepinephrine (Noguchi et al. 1998). Interestingly, cimicifugic acid $\mathrm{C}(0.3 \mathrm{mM})$ induced minimal contraction, whereas fukinolic acid and cimicifugic acid D at the same concentration acted as a relaxant. The contrasting effects might be explained by the differing substitution patterns in the hydroxycinnamic acid part, namely the caffeoyl group in the relaxing fukinolic acid and cimicifugic acid D and the 4-coumaroyl group in the contractive cimicifugic acid C. Cimicifugic acids A, B and E showed no vasoactive effects. Further experiments suggested that the relaxing effect could be explained by a decreased influx of extracellular $\mathrm{Ca}^{2+}$ through receptor-operated Ca-channels.

\section{Miscellaneous effects}

On the way to explain the effect of black cohosh extracts against hot flushes in menopausal women, an inhibitory effect of cimicifugic acids $\mathrm{A}$ and $\mathrm{B}$ on the serotonin $5 \mathrm{HT}_{7}$ receptor was observed with $\mathrm{IC}_{50}$ values of $120 \mu \mathrm{M}$ and $2.67 \mu \mathrm{M}$ (Farnsworth et al. 2008).

Shimoda et al. (2006) investigated the effect of an extract from aerial parts of $P$. japonicus on mast cell degranulation and found that fukinolic acid was most potent with an $\mathrm{IC}_{50}$ value of $4.8 \mu \mathrm{M}$. The compound could therefore be useful to suppress type I allergic reactions for example during hay fever.

\section{Influence on seed germination}

Besides a number of other factors, the germination of seeds is dependent on $\alpha$-amylase, an enzyme hydrolyzing the storage carbohydrate starch into metabolizable sugars enabling the growth of the seeds (Damaris et al. 2019). In a study on seed germination, the influence of fukinolic acid and cimicifugic acid A on seeds of two monocotyledonous and two dicotyledonous plants have been observed (Kusano et al. 1998). The grade of inhibition of germination and seedling growth (determined as root length) varied from plant species to plant species. Root length was 
reduced to an average of $35 \%$ by fukinolic acid and cimicifugic acid $\mathrm{A}$ and $18 \%$ by rosmarinic acid at a concentration of $0.3 \mathrm{mM}$. Both compounds presumably inhibited seed germination and root growth due to the interaction with $\alpha$-amylase and carboxypeptidase A. The latter enzyme is an exopeptidase cleaving aliphatic and aromatic $\mathrm{L}$-amino acids at the $\mathrm{C}$-terminus of a peptide (Barber and Fisher 1972). As both enzymes are participating in a variety of metabolic processes, further investigations on the hydroxycinnamic acid esters might be promising. The mean inhibitory concentrations $\left(\mathrm{IC}_{50}\right)$ of fukinolic acid were at $40 \mu \mathrm{M}$ for $\alpha$-amylase and $173 \mu \mathrm{M}$ for carboxypeptidase $\mathrm{A} . \mathrm{IC}_{50}$ values of cimicifugic acid $\mathrm{A}$ were $24.1 \mu \mathrm{M}$ for $\alpha$-amylase and $198 \mu \mathrm{M}$ for carboxypeptidase A. The positive control for $\alpha$-amylase acarbose displayed an $\mathrm{IC}_{50}$ of $92 \mu \mathrm{M}$ and the positive control for carboxypeptidase A 1,10-phenanthroline an $\mathrm{IC}_{50}$ of $421 \mu \mathrm{M}$ (Kusano et al. 1998). Therefore, both hydroxycinnamic acid esters were more potent than the acknowledged inhibitors for the respective enzymes. Cimicifugic and fukinolic acids thus might have allelopathic effects in the plants' environment.

\section{Conclusion}

Plants of the genera Actaea and Petasites growing in Europe, Eastern Asia and North America have been used in traditional medicine for the therapy of a multitude of diseases. In Eastern Asia, especially China, various Actaea (Cimicifuga) species are used in traditional Chinese medicine as well as as functional food ingredient. Here, the content of isoferulic acid indicates the quality of Cimicifugae rhizoma, consisting of A. foetida, A. heracleifolia and A. dahurica (Shen et al. 2013; Guo et al. 2017). In North America and Europe, Actaea (Cimicifuga) racemosa rhizome extracts are administered against premenstrual and postmenopausal afflictions mainly due to the observed estrogen-like effects of its triterpene lactone glycosides (e.g. actein and deoxyactein) (Borrelli et al. 2003; He et al. 2006).

Besides being part of the diet in Japan, despite the pyrrolizidine alkaloids present in this plant, $P$. japonicus has been used against asthma and allergic reactions (see review by Aydin et al. 2013). Petasin and related sesquiterpenoids are well known from other Petasites species (especially P. hybridus) due to their spasmolytic activity (Bachmann 2017).

Since the main pharmacological activities of Actaea (Cimicifuga) and Petasites extracts are caused by other natural compounds, the possible positive or negative effects of the hydroxycinnamic acid esters, namely the fukinolic and cimicifugic acids have been neglected. The quantities in which the hydroxycinnamic acid esters occur in the respective plants or plant organs and the extracts prepared thereof have, however, to be taken into account in order to assess their applicability as purified compounds and the possible side effects when using whole extracts. Calculating with data from Kruse (2000) the main hydroxycinnamic acid ester in rhizomes of A. racemosa is fukinolic acid with about 4-5 mg per g dry drug $(0.4-0.5 \%$ of the drug dry weight). Other cimicifugic acids are considerably less abundant. The data by Nuntanakorn et al. (2007) also indicate contents at or less than $1 \%$ in several Actaea species. Similarly, contents of about or less than $0.1 \%$ of the dry weight have been determined by Niu et al. (2019) in various Actaea species. Since the amounts of the hydroxycinnamic acids in plant material is rather restricted and only few plant species are known to produce these fukinolic and cimicifugic acids, biological activities requiring higher concentrations of these compounds do not appear to be promising to be exploited in near future. All the reported biological activities were gained from in vitro studies. In vivo studies specializing on the hydroxycinnamic acids of Actaea and Petasites species are lacking.

Much effort has been directed to evaluate the pharmacological effects of the extracts and the active compounds. Although the chemical composition of the active compounds has been elucidated and many biological activities have been characterized, there are still gaps in our knowledge of fukinolic and cimicifugic acids and their activities. The substitution pattern at the aromatic rings of the acids seems to determine anti-inflammatory (Löser et al. 2000), antioxidant (Nuntanakorn et al. 2007), antiviral (Ma et al. 2019), cytotoxic (Yim et al. 2012b) and vasoactive activities (Noguchi et al. 1998). However, it remains unclear, if every effect is relatable to structural differences on fukinolic and cimicifugic acids. Furthermore, not every medicinal aspect has been investigated in vivo. Probably the results might differ from those observed in vitro. Strikingly, the 
mechanism of action of cimicifugic acids and fukinolic acid has not been described yet and information on the bioavailability is lacking.

The extract from the rhizomes of Actaea (Cimicifuga) racemosa is commonly used for the relief of pre- and postmenopausal symptoms and the effect is related to its estrogen-like effects of triterpene lactone glycosides and hydroxycinnamic acid esters (Kruse et al. 1999; Borrelli et al. 2003; He et al. 2006). On the other hand, increased cell proliferation of MCF-7 breast cancer cells has been observed with fukinolic acid and cimicifugic acid G. Cimicifugic acids A and $\mathrm{B}$ have, however, been shown to have anti-tumor effects in a different breast cancer cell line (Kruse et al. 1999; Jiang et al. 2008b). Since the probability to suffer from breast cancer is increasing with the age of women, the use of Actaea (Cimicifuga) racemosa extracts for postmenopausal symptoms should probably be regarded more critically. Furthermore, cell viability assays have been performed in independent studies. Fukinolic and cimicifugic acids showed cytotoxicity in vivo even in the sub-micromolar range in different cancer cell-lines, but data regarding cytotoxic effects in non-cancer cell lines are lacking. Further investigations on the pharmacological efficiency of these hydroxycinnamic acid esters are needed for possible clinical applications.

Structurally related compounds such as rosmarinic acid (the ester of caffeic acid and 3,4-dihydroxyphenyllactic acid) or chlorogenic acid (caffeoyl-5quinic acid) are far better investigated for their pharmacological activities, probably due to their better availability. Moreover, these compounds occur widely throughout the plant kingdom. The multiple pharmacological activities of chlorogenic acid have recently e.g. been summarized by Miao and Xiang (2020) and those of rosmarinic acid by Amoah et al. (2016). This information may be used as a blueprint for further investigations of fukinolic and cimicifugic acids, although the structural differences in the noncaffeic acid part of the molecules might have a strong impact on their physiological behaviour.

Authors' contributions Anne Jahn and Maike Petersen both contributed to concept as well as data collection and analysis. Both authors wrote, read and approved the submitted version of the manuscript.
Funding Open Access funding enabled and organized by Projekt DEAL.

Data availability All reviewed data are published data. All sources have been cited.

\section{Declarations}

Conflict of interest The authors declare no conflicts of interest.

Open Access This article is licensed under a Creative Commons Attribution 4.0 International License, which permits use, sharing, adaptation, distribution and reproduction in any medium or format, as long as you give appropriate credit to the original author(s) and the source, provide a link to the Creative Commons licence, and indicate if changes were made. The images or other third party material in this article are included in the article's Creative Commons licence, unless indicated otherwise in a credit line to the material. If material is not included in the article's Creative Commons licence and your intended use is not permitted by statutory regulation or exceeds the permitted use, you will need to obtain permission directly from the copyright holder. To view a copy of this licence, visit http://creativecommons.org/licenses/by/4.0/.

\section{References}

Abu-Reidah IM, Arráez-Román D, Warad I, FernándezGutiérrez A, Segura-Carretero A (2017) UHPLC/MS2based approach for the comprehensive metabolite profiling of bean (Vicia faba L.) by-products: a promising source of bioactive constituents. Food Res Int 93:87-96. https://doi. org/10.1016/j.foodres.2017.01.014

Ae N, Arihara J, Okada K, Yoshihara T, Johansen C (1990) Phosphorus uptake by pigeon pea and its role in cropping systems of the Indian subcontinent. Science 248:477-480. https://doi.org/10.1126/science.248.4954.477

Amoah SKS, Sandjo LP, Kratz JM, Biavatti MW (2016) Rosmarinic acid-pharmaceutical and clinical aspects. Planta Med 82:388-406. https://doi.org/10.1055/s-0035-1568274

Aydin AA, Zerbes V, Parlar H, Letzel T (2013) The medical plant butterbur (Petasites): analytical and physiological (re)view. J Pharm Biomed Anal 75:220-229. https://doi. org/10.1016/j.jpba.2012.11.028

Bachmann C (2017) Der Pestwurzextrakt Ze 339—der Wandel einer Arzneipflanze. Schweiz Z Ganzheitsmed 29:327-329. https://doi.org/10.1159/000484878

Barber AK, Fisher JR (1972) A mechanism of action for carboxypeptidase A. Proc Natl Acad Sci USA 69:2970-2974. https://doi.org/10.1073/pnas.69.10.2970

Bittner M, Schenk R, Springer A, Melzig MF (2016) Economical, plain, and rapid authentication of Actaea racemosa $\mathrm{L}$. (syn. Cimicifuga racemosa, Black Cohosh) herbal raw material by resilient RP-PDA-HPLC and chemometric analysis. Phytochem Anal 27:318-325. https://doi.org/10. 1002/pca.2622 
Blascheck W (2016) Wichtl - Teedrogen und Phytopharmaka: ein Handbuch für die Praxis. Wiss Verlagsgesellschaft Stuttg 6 Aufl 2016:173-175 (ISBN 978-3-8047-3068-7)

Borrelli F, Izzo AA, Ernst E (2003) Pharmacological effects of Cimicifuga racemosa. Life Sci 73:1215-1229. https://doi. org/10.1016/s0024-3205(03)00378-3

Bridge W, Coleman F, Robertson A (1948) Constituents of "Cortex Piscidiae erythrinae." I. Structure of piscidic acid. J Chem Soc 1948:257-260

Buhren B, Schrumpf H, Hoff NP, Bölke E, Hilton S, Gerber PA (2016) Hyaluronidase: from clinical applications to molecular and cellular mechanisms. Eur J Med Res 21:5. https://doi.org/10.1186/s40001-016-0201-5

Burdette JE, Chen SN, Lu ZZ, Xu H, White BEP, Fabricant DS, Liu J, Fong HHS, Farnsworth NR, Constantinou AI, Van Breemen RB, Pezzuto JM, Bolton JL (2002) Black cohosh (Cimicifuga racemosa) protects against menadione-induced DNA damage through scavenging of reactive oxygen species: bioassay-directed isolation and characterization of active principles. J Agric Food Chem 50:7022-7028. https://doi.org/10.1021/jf020725h

Cabañas García E, Areche C, Gómez Aguirre YA, Jáuregui Rincón J, Cruz Sosa F, Pérez Molphe-Balch E (2020) Phytochemical profile of Coryphantha macromeris (Engelm.) Britton \& Rose (Cactaceae) obtained from in vitro culture. Rev Mex Ing Quim 19:239-249. https://doi.org/10. 24275/rmiq/Bio540

Carvalho KR, Silva AB, Torres MCM, Guimrães L, Rocha DD, Silveira ER, Costa-Lotufo LV, Braz-Filho R, Pessoa ODL (2015) Cytotoxic alkaloids from Hippeastrum solandriflorum Lindl. J Braz Chem Soc 26:1976-1980. https://doi. org/10.5935/0103-5053.20150176

Chen JY, Li PL, Tang XL, Wang SJ, Jiang YT, Shen L, Xu BM, Shao YL, Li GQ (2014) Cycloartane triterpenoids and their glycosides from rhizomes of Cimicifuga foetida. J Nat Prod 77:1997-2005. https://doi.org/10.1021/np500249v

Compton JA, Culham A, Jury SL (1998) Reclassification of Actaea to include Cimicifuga and Souliea (Ranunculaceae): phytogeny inferred from morphology, nrDNA ITS, and cpDNA trn L-F sequence variation. Taxon 47:593-634. https://doi.org/10.2307/1223580

Damaris RN, Lin Z, Yang P, He D (2019) The rice alphaamylase, conserved regulator of seed maturation and germination. Int J Mol Sci 20:450. https://doi.org/10.3390/ ijms 20020450

Díaz de Cerio E, Arráez-Román D, Segura-Carretero A, Ferranti P, Nicoletti R, Perrotta GM, Gómez-Caravaca AM (2018) Establishment of pressurized-liquid extraction by response surface methodology approach coupled to HPLC-DADTOF-MS for the determination of phenolic compounds of myrtle leaves. Anal Bioanal Chem 410:3547-3557. https:// doi.org/10.1007/s00216-018-0914-0

Ding P, Chen D (2008) Phenolic components of Radix Sophorae Tonkinensis. Zhongcaoyao 39:186-188

Fabricant DS, Nikolic D, Lankin DC, Chen SN, Jaki BU, Krunic A, van Breemen RB, Fong HHS, Farnsworth NR, Pauli GF (2005) Cimipronidine, a cyclic guanidine alkaloid from Cimicifuga racemosa. J Nat Prod 68:1266-1270. https:// doi.org/10.1021/np050066d

Farnsworth NR, Krause EC, Bolton JL, Pauli GF, van Breemen RB, Graham JG (2008) The University of Illinois at
Chicago/National Institutes of Health Center for Botanical Dietary Supplements Research for women's health: from plant to clinical use. Am J Clin Nutr 87:504S-508S. https:// doi.org/10.1093/ajen/87.2.504S

Freer PC, Clover AM (1901) Constituents of Jamaica DogWood. Pharm Arch 4:21-28

Geng P, Chen P, Sun J, McCoy JAH, Harnly JM (2019) Authentication of black cohosh (Actaea racemosa) dietary supplements based on chemometric evaluation of hydroxycinnamic acid esters and hydroxycinnamic acid amides. Anal Bioanal Chem 411:7147-7156. https://doi.org/10. 1007/s00216-019-02082-9

Gödecke T, Nikolic D, Lankin DC, Chen SN, Powell SL, Dietz B, Bolton JL, Van Breemen RB, Farnsworth NR, Pauli GF (2009) Phytochemistry of cimicifugic acids and associated bases in Cimicifuga racemosa root extracts. Phytochem Anal 20:120-133. https://doi.org/10.1002/pca.1106

Guo Y, Yin T, Wang X, Zhang F, Pan G, Lv H, Wang X, Orgah JO, Zhu Y, Wu H (2017) Traditional uses, phytochemistry, pharmacology and toxicology of the genus Cimicifuga: a review. J Ethnopharmacol 209:264-282. https://doi.org/ 10.1016/j.jep.2017.07.040

Hasa Y, Tazaki H (2004) Biosynthesis of fukinolic acid isolated from Petasites japonicus. Biosci Biotechnol Biochem 68:2212-2214. https://doi.org/10.1271/bbb.68.2212

He BJ, Liu ZY, Jin GS, Li YM (1980) Studies on an aqueous soluble active constituent of Chuan-Shan-Long (Dioscorea nipponica Makino). I. Isolation and identification of $p$ hydroxybenzyl tartaric acid (piscidic acid). Yao xue xue bao Acta Pharm Sin 15:764-765

He K, Pauli GF, Zheng B, Wang HK, Bai NS, Peng TS, Roller M, Zheng QY (2006) Cimicifuga species identification by high performance liquid chromatography-photodiode array/mass spectrometric/evaporative light scattering detection for quality control of black cohosh products. J Chromatogr A 1112:241-254. https://doi.org/10.1016/j. chroma.2006.01.004

Heller W, Tamm C (1975) Fukiinsäure und 3'-O-Methylfukiinsäure, zwei phenolische Hydroxycarbonsäuren aus Piscidia erythrina. Helv Chim Acta 58:974-979. https://doi. org/10.1002/hlca.19750580403

Henneicke-von-Zepelin HH (2017) 60 years of Cimicifuga racemosa medicinal products. Clinical research milestones, current study findings and current development. Wien Med Wochenschr 167:147-159. https://doi.org/10. 1007/s10354-016-0537-z

Hiemori-Kondo M, Nii M (2020) In vitro and in vivo evaluation of antioxidant activity of Petasites japonicus Maxim. flower buds extracts. Biosci Biotechnol Biochem 84:621-632. https://doi.org/10.1080/09168451.2019. 1691913

Ho P, Liu C, Chin K, Li Y (1980) Isolation and identification of $p$-hydroxybenzyltartaric acid (piscidic acid): a water soluble active constituent of Dioscorea nipponica. Yaoxue Tongbao 15:39

Huang Y, Jiang B, Nuntanakorn P, Kennelly EJ, Shord S, Lawal TO, Soni KK, Mahady GB (2010) Fukinolic acid derivatives and triterpene glycosides from black cohosh inhibit CYP isozymes, but are not cytotoxic to Hep-G2 cells in vitro. Curr Drug Safety 5:118-124. https://doi.org/10. 2174/157488610790936150 
Ishikawa S, Adu-Gyamfi JJ, Nakamura T, Yoshihara T, Watanabe T, Wagatsuma T (2002) Genotypic variability in phosphorus solubilizing activity of root exudates by pigeonpea grown in low-nutrient environments. Plant Soil 245:71-81. https://doi.org/10.1023/A:1020659227650

Iwanaga A, Kusano G, Warashina T, Miyase T (2010a) Hyaluronidase inhibitors from "Cimicifugae rhizoma" (a mixture of the rhizomes of Cimicifuga dahurica and $C$. heracleifolia). J Nat Prod 73:573-578. https://doi.org/10. 1021/np900675n

Iwanaga A, Kusano G, Warashina T, Miyase T (2010b) Phenolic constituents of the aerial parts of Cimicifuga simplex and Cimicifuga japonica. J Nat Prod 73:609-612. https://doi. org/10.1021/np900752t

Jiang B, Lyles JT, Reynertson KA, Kronenberg F, Kennelly EJ (2008a) Stability evaluation of selected polyphenols and triterpene glycosides in black cohosh. J Agric Food Chem 56:9510-9519. https://doi.org/10.1021/jf802481w

Jiang B, Reynertson KA, Keller AC, Einbond LS, Bemis DL, Weinstein IB, Kronenberg F, Kennelly EJ (2008b) Extraction methods play a critical role in chemical profile and biological activities of black cohosh. Nat Prod Commun 3:1519-1532. https://doi.org/10.1177/ $1934578 x 0800300925$

Kim KM, Im AR, Lee S, Chae S (2017) Dual protective effects of flavonoids from Petasites japonicus against UVB-induced apoptosis mediated via HSF-1 activated heat shock proteins and Nrf2-activated heme oxygenase-1 pathways. Biol Pharm Bull 40:765-773. https://doi.org/10.1248/bpb. b16-00691

Kim SM, Kang SW, Jeon JS, Jung YJ, Kim CY, Pan CH, Um BH (2012) Rapid identification and evaluation of antioxidant compounds from extracts of Petasites japonicus by hyphenated-HPLC techniques. Biomed Chromatogr 26:199-207. https://doi.org/10.1002/bmc.1646

Kitajima M, Okabe K, Yoshida M, Nakabayashi R, Saito K, Kogure N, Takayama H (2019) New otonecine-type pyrrolizidine alkaloid from Petasites japonicus. J Nat Med 73:602-607. https://doi.org/10.1007/s11418-019-01285-9

Krogh A (1969) Screening tests for phorbic and piscidic acids in plants by thin-layer chromatography. Acta Chem Scand 23:3590-3591. https://doi.org/10.3891/acta.chem.scand. 23-3590

Krogh A (1967) Thin-layer chromatographic method for the separation and identification of phorbic and piscidic acids. Acta Chem Scand 21:1372-1374. https://doi.org/10.3891/ acta.chem.scand.21-1372

Kruse SO (2000) Phytochemische Arbeiten zu Cimicifuga racemosa (L.) Nutt. - Gewinnung und Analytik wirksamer Fraktionen und Inhaltsstoffe. Dissertation, Westfälische Wilhelms-Universität Münster

Kruse SO, Löhning A, Pauli GF, Winterhoff H, Nahrstedt A (1999) Fukiic and piscidic acid esters from the rhizome of Cimicifuga racemosa and the in vitro estrogenic activity of fukinolic acid. Planta Med 65:763-764. https://doi.org/10. 1055/s-2006-960862

Kusano G (2001) Studies on the constituents of Cimicifuga species. Yakugaku Zasshi 121:497-521. https://doi.org/10. 1248/yakushi.121.497

Kusano A, Seyama Y, Nagai M, Shibano M, Kusano G (2001) Effects of fukinolic acid and cimicifugic acids from
Cimicifuga species on collagenolytic activity. Biol Pharm Bull 24:1998-12021. https://doi.org/10.1248/bpb.24.1198

Kusano G, Takahira M, Shibano M, Kusano A, Okamoto Y, Tsujibo H, Numata A, Inamori Y (1998) Studies on inhibitory activities of fukiic acid esters on germination $\alpha$ amylase and carboxypeptidase A. Biol Pharm Bull 21:997-999. https://doi.org/10.1248/bpb.21.997

Kwak CS, Yang J, Shin CY, Chung JH (2018) Topical or oral treatment of peach flower extract attenuates UV-induced epidermal thickening, matrix metalloproteinase-13 expression and pro-inflammatory cytokine production in hairless mice skin. Nutr Res Pract 12:29-40. https://doi. org/10.4162/nrp.2018.12.1.29

Lata H, Bedir E, Hosick A, Ganzera M, Khan I, Moraes RM (2002) In vitro plant regeneration from leaf-derived callus of Cimicifuga racemosa. Planta Med 68:912-915. https:// doi.org/10.1055/s-2002-34933

Leach MJ, Moore V (2012) Black cohosh (Cimicifuga spp.) for menopausal symptoms. Cochrane DB Syst Rev 9:CD007244. https://doi.org/10.1002/14651858. CD007244.pub2

Lee JS, Jeong M, Park S, Ryu SM, Lee J, Song Z, Guo Y, Choi JH, Lee D, Jang DS (2019) Chemical constituents of the leaves of butterbur (Petasites japonicus) and their antiinflammatory effects. Biomolecules 9:806. https://doi.org/ 10.3390/biom9120806

Li W, Sun Y, Liang W, Fitzloff JF, van Breemen RB (2003) Identification of caffeic acid derivatives in Actaea racemosa (Cimicifuga racemosa, black cohosh) by liquid chromatography/tandem mass spectrometry. Rapid Commun Mass Sp 17:978-982. https://doi.org/10.1002/rcm. 1008

Löser B, Kruse SO, Melzing MF, Nahrstedt A (2000) Inhibition of neutrophil elastase activity by cinnamic acid derivatives from Cimicifuga racemosa. Planta Med 66:751-753. https://doi.org/10.1055/s-2000-9563

Ma Y, Cong W, Huang H, Sun L, Mai AH, Boonen K, Maryam W, De Borggraeve W, Luo G, Liu Q, Schoofs L, Van Kuppeveld F, Neyts J, Mirabelli C, Luyten W (2019) Identification of fukinolic acid from Cimicifuga heracleifolia and its derivatives as novel antiviral compounds against enterovirus A71 infection. Int J Antimicrob Agents 53:128-136. https://doi.org/10.1016/j.ijantimicag.2018. 07.014

Maier C, Conrad J, Carle R, Weiss J, Schweiggert RM (2015) Phenolic constituents in commercial aqueous Quillaja (Quillaja saponaria Molina) wood extracts. J Agr Food Chem 63:1756-1762. https://doi.org/10.1021/jf506277p

Melzig MF, Löser B, Lobitz GO, Tamayo-Castillo G, Merfort I (1999) Inhibition of granulocyte elastase activity by caffeic acid derivatives. Pharmazie 54:712

Miao M, Xiang L (2020) Pharmacological action and potential targets of chlorogenic acid. Adv Pharmacol 87:71-88. https://doi.org/10.1016/bs.apha.2019.12.002

Min BS, Cui HS, Lee HK, Sok DE, Kim MR (2005) A new furofuran lignan with antioxidant and antiseizure activities from the leaves of Petasites japonicus. Arch Pharm Res 28:1023-1026. https://doi.org/10.1007/BF02977395

Missaoui M, D’Antuono I, D’Imperio M, Linsalata V, Boukhchina S, Logrieco AF, Cardinali A (2020) Characterization of micronutrients, bioaccessibility and antioxidant activity 
of Prickly Pear cladodes as functional ingredient. Molecules 25:2176. https://doi.org/10.3390/ molecules 25092176

Miyazawa M, Teranishi A, Ishikawa Y (2003) Components of the essential oil from Petasites japonicus. Flavour Frag J 18:231-233. https://doi.org/10.1002/ffj.1203

Moore JA, Eng S (1956) Some new constituents of Piscidia erythrina L. J Am Chem Soc 78:395-398. https://doi.org/ 10.1021/ja01583a039

Mukhopadhyay S, Luthria DL, Robbins RJ (2006) Optimization of extraction process for phenolic acids from black cohosh (Cimicifuga racemosa) by pressurized liquid extraction. J Sci Food Agric 86:156-162. https://doi.org/10.1002/jsfa. 2326

Murashige M, Skoog F (1962) A revised medium for rapid growth and bioassay with tobacco tissue culture. Physiol Plant 15:473-497

Nair PC, Mc Kinnon RA, Miners JO (2016) Cytochrome P450 structure-function: insights from molecular dynamics simulations. Drug Metab Rev 48:434-425. https://doi.org/ 10.1080/03602532.2016.1178771

Nikolić D, Gödecke T, Chen SN, White J, Lankin DC, Pauli GF, van Breemen RB (2012) Mass spectrometric dereplication of nitrogen-containing constituents of Black Cohosh (Cimicifuga racemosa L.). Fitoterapia 83:441-460. https:// doi.org/10.1016/j.fitote.2011.12.006

Niu X, Qin R, Zhao Y, Han L, Lu J, Lv C (2019) Simultaneous determination of 19 constituents in Cimicifugae Rhizoma by HPLC-DAD and screening for antioxidants through DPPH free radical scavenging assay. Biomed Chromatogr 33:3. https://doi.org/10.1002/bmc.4624

Noguchi M, Nagai M, Koeda M, Nakayama S, Sakurai N, Takahira M, Kusano G (1998) Vasoactive effects of cimicifugic acids $C$ and $D$ and fukinolic acid in cimicifuga rhizome. Biol Pharm Bull 21:1163-1168. https://doi.org/ $10.1248 / \mathrm{bpb} .21 .1163$

Nordal A, Ogner G (1964) The nonvolatile acids of succulent plants exhibiting a marked diurnal oscillation in their acid content. I. The detection of piscic acid in Agave americana. Acta Chem Scand 18:1979-1983. https://doi.org/10.3891/ acta.chem.scand.18-1979

Nordal A, Gether J, Haustveit G (1966a) Non-volatile acids of succulent plants exhibiting a marked diurnal oscillation in their acid content. II. Demonstration of piscidic acid as one of the predominating acids in Opuntia ficus-indica. Acta Chem Scand 20:1431-1432. https://doi.org/10.3891/acta. chem.scand.20-1431

Nordal A, Haustveit G, Gether J (1966b) Preparation of piscidic acid and some of its derivatives from Jamaica dogwood, Piscidia erythrina. Medd Nor Farm Selsk 28:225-228

Nuntanakorn P, Jiang B, Einbond LS, Yang H, Kronenberg F, Weinstein IB, Kennelly EJ (2006) Polyphenolic constituents of Actaea racemosa. J Nat Prod 69:314-318. https://doi.org/10.1021/np0501031

Nuntanakorn P, Jiang B, Yang H, Cervantes-Cervantes M, Kronenberg F, Kennelly EJ (2007) Analysis of polyphenolic compounds and radical scavenging activity of four American Actaea species. Phytochem Anal 18:219-228. https://doi.org/10.1002/pca.975
Okumura FS, Smeby RR, String FM (1955) Piscidic acid from Narcissus poeticus. J Am Chem Soc 77:5750-5751. https:// doi.org/10.1021/ja01626a094

Otani T, Ae N, Tanaka H (1996) Phosphorus (P) uptake mechanisms of crops grown in soils with low P status. II. Significance of organic acids in root exudates of pigeonpea. Soil Sci Plant Nutr 42:553-560. https://doi.org/10.1080/ 00380768.1996.10416324

Ożarowski M, Przystanowicz J, Adamczak A (2013) Phytochemical, pharmacological and clinical studies of Petasites hybridus (L.) P. Gaertn., B. Mey. \& Scherb. A Review. Herba Pol 59:108-128. https://doi.org/10.2478/hepo2013-0028

Powers CN, Setzer WN (2016) An in-silico investigation of phytochemicals as antiviral agents against Dengue fever. Comb Chem High Throughput Screen 19:516-536. https:// doi.org/10.2174/1386207319666160506123715

Qin RL, Lv CN, Zhao Y, Zhao YD, Yu Y, Lu JC (2017) Assessment of phenolics contents and antioxidant properties in Cimicifuga dahurica (Turcz.) Maxim during drying process. Ind Crop Prod 107:288-296. https://doi.org/10. 1016/j.indcrop.2017.06.004

Qiu F, McAlpine JB, Krause EC, Chen SN, Pauli GF (2014) Pharmacognosy of black cohosh: The phytochemical and biological profile of a major botanical dietary supplement. In: Kinghorn AD, Falk H, Kobayashi J (eds) Progress in the chemistry of organic natural products. Springer, Cham, pp 1-68. https://doi.org/10.1007/978-3-319-04900-7_1

Queffélec C, Bailly F, Mbemba G, Mouscadet JF, Debyser Z, Witvrouw M, Cotelle P (2008) The total synthesis of fukiic acid, an HIV-1 integrase inhibitor. Eur J Med Chem 43:2268-2271. https://doi.org/10.1016/j.ejmech.2007.12. 013

Saada M, Falleh H, Catarino MD, Cardoso SM, Ksouri R (2018) Plant growth modulates metabolites and biological activities in Retama raetam (Forssk.) Webb. Molecules 23:2177. https://doi.org/10.3390/molecules23092177

Sakai S, Suzuki Y, Itagaki T, Tsujisawa H, Makino TT (2008) On the function of hermaphrodite florets in female inflorescences of Petasites japonicus (Asteraceae). Botany 86:179-184. https://doi.org/10.1139/B07-121

Sakamura S, Yoshihara T, Toyoda K (1969) Fukiic acid isolated from a hydrolysate of a polyphenol in Petasites japonicus. Agric Biol Chem 33:1795-1797. https://doi.org/10.1080/ 00021369.1969.10859543

Sakamura S, Yoshihara T, Toyoda K (1973) The constituents of Petasites japonicus: structures of fukiic acid and fukinolic acid. Agric Biol Chem 37:1915-1921. https://doi.org/10. 1080/00021369.1973.10860912

Sakurai N, Kozuka M, Tokuda H, Nobukuni Y, Takayasu J, Nishino H, Kusano A, Kusano G, Nagai M, Sakurai Y, Lee KH (2003) Antitumor agents 220. Antitumor-promoting effects of cimigenol and related compounds on EpsteinBarr virus activation and two-stage mouse skin carcinogenesis. Bioorg Med Chem Lett 11:1137-1140. https://doi. org/10.1016/S0968-0896(02)00432-7

Sakurai N, Wu JH, Sashida Y, Mimaki Y, Nikaido T, Koike K, Itokawa H, Lee KH (2004) Anti-AIDS agents. Part 57: Actein, an anti-HIV principle from the rhizome of Cimicifuga racemosa (black cohosh), and the anti-HIV activity 
of related saponins. Bioorg Med Chem Lett 14:1329-1332. https://doi.org/10.1016/j.bmcl.2003.12.035

Salari S, Amiri MS, Ramezani M, Moghadam AT, Elyasi S, Sahebkar A, Emami SA (2021) Ethnobotany, phytochemistry, traditional and modern uses of Actaea racemosa $\mathrm{L}$. (Black cohosh): a review. In: Barreto GE, Sahebkar A (eds) Pharmacological properties of plant-derived natural products and implications for human health. Advances in Experimental Medicine and Biology, vol 1308. Springer, Cham, pp 401-449. https://doi.org/10.1007/978-3-03064872-5_24

Shen BJ, Qin KM, Zhang XH, Liu QD, Cai H, Liu X, Cai BC (2013) Study on the quality evaluation of cimicifugae rhizoma from different producing areas by HPLC fingerprint. China J Chin Mat Med 38:2155-2158

Shimoda H, Tanaka J, Yamada E, Morikawa T, Kasajima N, Yoshikawa M (2006) Anti type I allergic property of Japanese Butterbur extract and its mast cell degranulation inhibitory ingredients. J Agric Food Chem 54:2915-2920. https://doi.org/10.1021/jf052994o

Shoulders MD, Raines RT (2009) Collagen structure and stability. Annu Rev Biochem 78:929-958. https://doi.org/10. 1146/annurev.biochem.77.032207.120833

Siedle B, Murillo R, Hucke O, Labahn A, Merfort I (2003) Structure activity relationship studies of cinnamic acid derivatives as inhibitors of human neutrophil elastase revealed by ligand docking calculations. Pharmazie 58:337-339

Sobeh M, Rezq S, Sabry OM, Abdelfattah MAO, El Raey MA, El-Kashak WA, El-Shazly AM, Mahmoud MF, Wink M (2020) Albizia anthelmintica: HPLC-MS/MS profiling and in vivo anti-inflammatory, pain killing and antipyretic activities of its leaf extract. Biomed Pharmacother 115:108882. https://doi.org/10.1016/j.biopha.2019. 108882

Stander MA, Van Wyk BE, Taylor MJC, Long HS (2017) Analysis of phenolic compounds in rooibos tea (Aspalathus linearis) with a comparison of flavonoid-based compounds in natural populations of plants from different regions. J Agric Food Chem 65:10270-10281. https://doi.org/10. 1021/acs.jafc.7b03942

Stander MA, Redelinghuys H, Masike K, Long H, Van Wyk BE (2019) Patterns of variation and chemosystematic significance of phenolic compounds in the genus Cyclopia (Fabaceae, Podalyrieae). Molecules 24:2352. https://doi. org/10.3390/molecules24132352

Steinbrecher T, Case DA, Labahn A (2006) A multistep approach to structure-based drug design: studying ligand binding at the human neutrophil elastase. J Med Chem 49:1837-1844. https://doi.org/10.1021/jm0505720

Stromeier S, Petereit F, Nahrstedt A (2005) Phenolic esters from the rhizomes of Cimicifuga racemosa do not cause proliferation effects in MCF-7 cells. Planta Med 71:495-500. https://doi.org/10.1055/s-2005-864148

Takahira M, Kusano A, Shibano M, Kusano G, Miyase T (1998a) Piscidic acid and fukiic acid esters from Cimicifuga simplex. Phytochemistry 49:2115-2119. https://doi. org/10.1016/S0031-9422(98)00407-5

Takahira M, Kusano A, Shibano M, Kusano G, Sakurai N, Nagai M, Miyase T (1998b) Three new fukiic acid esters, cimicifugic acids $\mathrm{A}, \mathrm{B}$ and $\mathrm{C}$, from Cimicifuga simplex
WORMSK. Chem Pharm Bull 46:362-365. https://doi.org/ $10.1248 / \mathrm{cpb} .46 .362$

Tardáguila-García A, García-Morales E, García-Alamino JM, Álvaro-Afonso FJ, Molines-Barroso RJ, Lázaro-Martínez JL (2019) Metalloproteinases in chronic and acute wounds: a systematic review and meta-analysis. Wound Repair Regen 27:415-420. https://doi.org/10.1111/wrr.12717

Teles FFF, Price RL, Whiting FM, Reid BL (1994) Circadian variation of non-volatile organic acids in the prickly pear (Opunita ficus indica L.). Rev Ceres 41:614-622. https:// doi.org/10.3891/acta.chem.scand.21-1372

Thomet OAR, Wiesmann UN, Blaser K, Simon HU (2001) Differential inhibition of inflammatory effector functions by petasin, isopetasin and neopetasin in human eosinophils. Clin Exp Allergy 31:1310-1320. https://doi.org/10.1046/j. 1365-2222.2001.01158.x

Toshima H, Saito M, Yoshihara T (1999) Total synthesis of (+)(2S,3R)-piscidic acid via catalytic asymmetric dihydroxylation of a trisubstituted olefin. Biosci Biotechnol Biochem 63:964-967. https://doi.org/10.1271/bbb.63.964

Touati R, Santos SAO, Rocha SM, Belhamel K, Silvestre AJD (2017) Phenolic composition and biological prospecting of grains and stems of Retama sphaerocarpa. Ind Crops Prod 95:244-255. https://doi.org/10.1016/j.indcrop.2016.10. 027

Tys J, Szopa A, Lalak J, Chmielewska M, Serefko A, Poleszak E (2015) A botanical and pharmacological description of Petasites species. Curr Iss Pharm Med Sci 28:151-154. https://doi.org/10.1515/cipms-2015-0062

Valente IM, Maia MRG, Malushi N, Oliveira HM, Papa L, Rodrigues JA, Fonseca AJM, Cabrita ARJ (2018) Profiling of phenolic compounds and antioxidant properties of European varieties and cultivars of Vicia faba L. pods. Phytochemistry 152:223-229. https://doi.org/10.1016/j. phytochem.2018.05.011

Wang G, Ma C (2009) Studies on phenolic compounds from Sophora alopecuroides. Zhongguo Zhongyao Zazhi 34:1238-1240

Wang C, Zhang N, Wang Z, Qi Z, Zhu H, Zheng B, Li P, Liu J (2017a) Nontargeted metabolomic analysis of four different parts of Platycodon grandiflorum grown in Northeast China. Molecules 22:1280. https://doi.org/10.3390/ molecules22081280

Wang ZY, Wang Q, Han YQ, Jiang M, Gao J, Miao Y, Bai G (2017b) Bioactivity-based UPLC/Q-TOF/MS strategy for screening of anti-inflammatory components from Cimicifugae rhizoma. Chin Chem Lett 28:476-481. https://doi. org/10.1016/j.cclet.2016.11.021

Wang R, Deng X, Gao Q, Wu X, Han L, Gao X, Zhao S, Chen W, Zhou R, Li Z, Bai C (2020) Sophora alopecuroides L.: an ethnopharmacological, phytochemical, and pharmacological review. J Ethnopharmacol 248:112172. https://doi. org/10.1016/j.jep.2019.112172

Wang S, Jin DQ, Xie C, Wang H, Wang M, Xu J, Guo Y (2013) Isolation, characterization, and neuroprotective activities of sesquiterpenes from Petasites japonicus. Food Chem 141:2075-2082. https://doi.org/10.1016/j.foodchem.2013. 04.116

Watanabe S, Hashimoto K, Tazaki H, Iwamoto Y, Shinohara N, Satoh K, Sakagami H (2007) Radical scavenging activity and inhibition of macrophage NO production by fukinolic 
acid, a main phenolic constituent in Japanese butterbur (Petasites japonicus). Food Sci Technol Res 13:366-371. https://doi.org/10.3136/fstr.13.366

Watanabe K, Mimaki Y, Sakagami H, Sashida Y (2002) Cycloartane glycosides from the rhizomes of Cimicifuga racemosa and their cytotoxic activities. Chem Pharm Bull (Tokyo) 50:121-125. https://doi.org/10.1248/cpb.50.121

Werner V, Petersen M (2019) A BAHD hydroxycinnamoyltransferase from Actaea racemosa catalyses the formation of fukinolic and cimicifugic acids. Planta 250:475-485. https://doi.org/10.1007/s00425-019-03181-8

Yannai S (2012) Dictionary of food compounds, 2nd edn. CRC Press, Boca Raton

Yim SH, Kim HJ, Jeong N, Park KD, Lee YJ, Cho SD, Lee IS (2012a) Structure-guided identification of novel phenolic and phenolic amide allosides from the rhizomes of Cimicifuga heracleifolia. Bull Korean Chem Soc 33:1253-1258. https://doi.org/10.5012/bkcs.2012.33.4. 1253

Yim SH, Kim HJ, Park SH, Kim J, Williams DR, Jung DW, Lee IS (2012b) Cytotoxic caffeic acid derivatives from the rhizomes of Cimicifuga heracleifolia. Arch Pharm Res 35:1559-1565. https://doi.org/10.1007/s12272-012-09060
Yoshihara T, Ichihara A, Nuibe H, Sakamura S, Sugita M, Imamoto S, Senoh S (1974) The stereochemistry of fukiic acid and its correlation with piscidic acid. Agric Biol Chem 38:121-126. https://doi.org/10.1271/bbb1961.38.121

Yu Y, Lv CN, Qin RL, Lv MY, Li Y, Lu JC (2019) Unique phenolic constituent in Cimicifuga dahurica (Turcz.) Maxim. through Box-Behnken design and response surface methodology. J Sep Sci 42:2550-2560. https://doi.org/10. 1002/jssc.201900274

Zhang C, Ma Y, Gao HM, Liu XQ, Chen LM, Zhang QW, Wang ZM, Li AP (2013) Non-alkaloid components from Sophora flavescens. Zhongguo zhongyao zazhi = China Journal of Chinese Materia Medica 38:3520-3524. https://doi.org/10. 4268/cjcmm20132022

Zhao M, Duan JA, Che CT (2007) Isoflavanones and their $O$ glycosides from Desmodium styracifolium. Phytochemistry 68:1471-1479. https://doi.org/10.1016/j.phytochem. 2007.02.015

Publisher's Note Springer Nature remains neutral with regard to jurisdictional claims in published maps and institutional affiliations. 